Archived version from NCDOCKS Institutional Repository http://libres.uncg.edu/ir/asu/

\title{
Appalachľă
}

B O O N E, NORT H CAROL I N A

\section{New Insight Into The Origin Of Manganese Oxide Ore Deposits In The Appalachian Valley And Ridge Of Northeastern Tennessee And Northern Virginia, USA}

\author{
By: Sarah K. Carmichael, Daniel H. Doctor, Crystal G. Wilson, Joshua Feierstein, and Ryan J. McAleer
}

\begin{abstract}
Manganese oxide deposits have long been observed in association with carbonates within the Appalachian Mountains, but their origin has remained enigmatic for well over a century. Ore deposits of Mn oxides from several productive sites located in eastern Tennessee and northern Virginia display morphologies that include botryoidal and branching forms, massive nodules, breccia matrix cements, and fracture fills. The primary ore minerals include hollandite, cryptomelane, and romanèchite. Samples of $\mathrm{Mn}$ oxides from multiple localities in these regions were analyzed using electron microscopy, X-ray analysis, Fourier transform infrared spectroscopy, and trace/rare earth element geochemistry. The samples from eastern Tennessee have biological morphologies, contain residual biopolymers, and exhibit REE signatures that suggest the ore formation was due to supergene enrichment (likely coupled with microbial activity). In contrast, several northern Virginia ores hosted within quartz-sandstone breccias exhibit petrographic relations, mineral morphologies, and REE signatures indicating inorganic precipitation, and a likely hydrothermal origin with supergene overprinting. Nodular accumulations of Mn oxides within weathered alluvial deposits that occur near to breccia-hosted Mn deposits in Virginia show geochemical signatures that are distinct from the breccia matrices, and appear to reflect remobilization of earlier-emplaced $\mathrm{Mn}$ and concentration within supergene traps. Based on the proximity of all of the productive ore deposits to mapped faults or other zones of deformation, we suggest that the primary source of all of the Mn may have been deep- seated, and that Mn oxides with supergene and/or biological characteristics result from the local remobilization and concentration of this primary Mn.
\end{abstract}

Carmichael, S. K., Doctor, D. H., Wilson, C. G., Feierstein, J., and McAleer, R. J., 2017, New insight into the origin of manganese oxide ore deposits in the Appalachian Valley and Ridge of northeastern Tennessee and northern Virginia, USA: Geological Society of America Bulletin 129 (9-10), p. 1158-1180. The copy of record is available from GSA Bulletin, https://doi.org/10.1130/B31682.1. 
Carmichael, S. K., Doctor, D. H., Wilson, C. G., Feierstein, J., and McAleer, R. J., 2017, New insight into the origin of manganese oxide ore deposits in the Appalachian Valley and Ridge of northeastern Tennessee and northern Virginia, USA: Geological Society of America Bulletin 129 (9-10), p. 1158-1180.

\title{
New insight into the origin of manganese oxide ore deposits in the Appalachian Valley and Ridge of northeastern Tennessee and northern Virginia, USA
}

\author{
Sarah K. Carmichael ${ }^{1}$, Daniel H. Doctor ${ }^{2}$, Crystal G. Wilson ${ }^{1}$, Joshua Feierstein ${ }^{1,3}$, and Ryan J. McAleer ${ }^{2}$ \\ ${ }_{1}^{1}$ Department of Geology, ASU Box 32067, Appalachian State University, Boone, NC, 28608 \\ 2 U.S. Geological Survey, 12201 Sunrise Valley Drive, MS 926A, Reston, VA, 20192 \\ ${ }^{3}$ GTA Associates, 5605 Chapel Hill Road, Suite 112, Raleigh, NC 27607
}

Corresponding author: Sarah K. Carmichael, ASU Box 32067, Boone, NC, 28608; carmichaelsk@appstate.edu; 828-262-8471

\begin{abstract}
Manganese oxide deposits have long been observed in association with carbonates within the Appalachian Mountains, but their origin has remained enigmatic for well over a century. Ore deposits of Mn oxides from several productive sites located in eastern Tennessee and northern Virginia display morphologies that include botryoidal and branching forms, massive nodules, breccia matrix cements, and fracture fills. The primary ore minerals include hollandite, cryptomelane, and romanèchite. Samples of Mn oxides from multiple localities in these regions were analyzed using electron microscopy, X-ray analysis, Fourier transform infrared spectroscopy, and trace/rare earth element geochemistry. The samples from eastern Tennessee have biological morphologies, contain residual biopolymers, and exhibit REE signatures that suggest the ore formation was due to supergene enrichment (likely coupled with microbial activity). In contrast, several northern Virginia ores hosted within quartz-sandstone breccias exhibit petrographic relations, mineral morphologies, and REE signatures indicating inorganic precipitation, and a likely hydrothermal origin with supergene overprinting. Nodular accumulations of Mn oxides within weathered alluvial deposits that occur near to breccia-hosted Mn deposits in Virginia show geochemical signatures that are distinct from the breccia matrices, and appear to reflect remobilization of earlier-emplaced Mn and concentration within supergene traps. Based on the proximity of all of the productive ore deposits to mapped faults or other zones of deformation, we suggest that the primary source of all of the Mn may have been deepseated, and that $\mathrm{Mn}$ oxides with supergene and/or biological characteristics result from the local remobilization and concentration of this primary Mn.
\end{abstract}

\section{INTRODUCTION}

Manganese oxide, hydroxide, and oxyhydroxide minerals (generally referred to as Mn oxides) form more than 30 distinct minerals and are both economically and environmentally important (Post, 1999). Mn oxide ores are commonly found as deposits in association with Paleozoic carbonate sediments throughout the Appalachians (Figure 1 ), and were mined and commercially prospected until the end of World War II. They have been described in detail in Alabama and Georgia (Harder, 1910; Hull et al., 1919; Pierce, 1944; Watson, 1909), Tennessee (King and Ferguson, 1960; King et al., 1944; Pierce, 1944; Reichert, 1942; Rodgers, 1945, 1948; Stose and Schrader, 1923),
Virginia (Force and Cox, 1991; Hack, 1965; Hewett, 1916; Hewett et al., 1918; Jonas, 1942; Miller, 1944; Stose and Stose, 1957; Stose and Miser, 1922; Stose et al., 1919), Maryland (Hewett, 1916), Pennsylvania (Bikerman et al., 1999; Foose, 1945), and Vermont (Dana, 1877; Harder, 1910). Due to the limitations of the available technology in nearly all of the existing studies, much of what is currently known about these ores is known from field assessments, optical methods, limited X-ray data, and major element whole rock geochemistry. This study is the first detailed study of Appalachian manganese deposits to be conducted in over 50 years, and provides new insights into the 


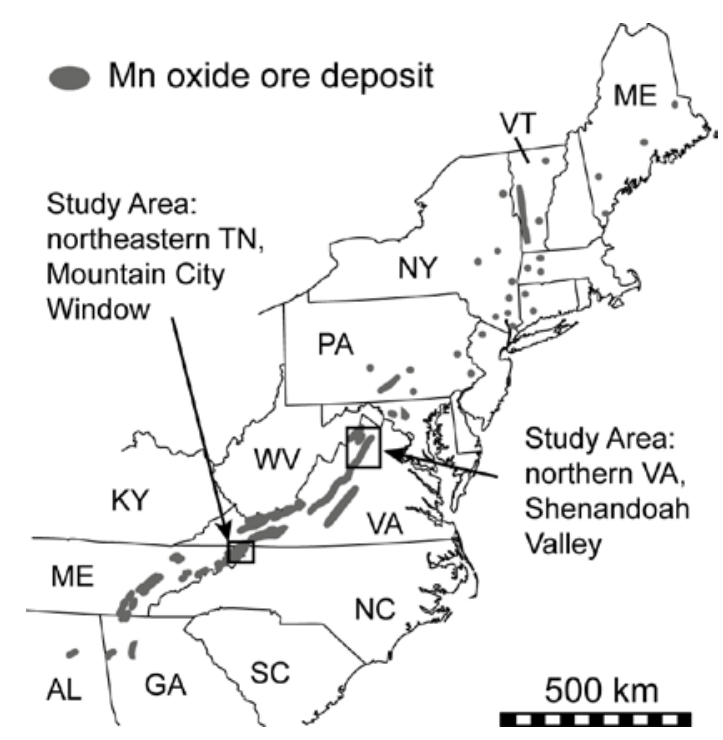

Figure 1. Map of Mn oxide deposits in the central and southern Appalachians, modified from Stose (1920) and Hoffman (1957). Ore mineralogy for many of these locations is described in detail in Hewett and Fleischer (1960).

formation of these enigmatic deposits via detailed geochemistry, electron microscopy, and other techniques that were not possible in the original studies.

The origin of these ores has long been debated; even the earliest investigators could not agree on how they formed. While some proposed that the Mn oxides formed in place as residuum from local Mn-bearing rocks (Dana, 1877; Penrose, 1891; Stose et al., 1919; Stose and Schrader, 1923), others suggested supergene formation from Mn-rich fluids derived from stratigraphically higher rocks (Harder, 1910; Reichert, 1942), as weathered residuum from stratigraphically higher rocks (Hull et al., 1919), or from recrystallization of hydrothermal deposits (Kesler, 1941). However, nearly all of these early studies recognized the complexity of these sites, and Hull et al. (1919, p. 72) sagely noted that "Some of the largest manganese ore deposits in the district do not show the clearly defined relations of ores and foot wall previously described, for the large deposits are probably complex accumulations, and, having been produced by several secondary causes, they do not show a clear and simple mode of occurrence." Despite numerous field surveys for potentially profitable $\mathrm{Mn}$ ore deposits in the following 30 years after Hull's assessment in 1919, no new hypotheses were proposed until additional mapping showed that some ore deposits in southwest Virginia were coeval with Pleistocene fossils and that Mn ore formation was not constrained by time but could occur wherever and whenever local conditions were favorable (Miser, 1950). Since that time, no new hypotheses have been proposed.

Given the prolonged lack of consensus on these unusual ore bodies, this study revisits questions that have been debated for nearly 140 years and largely ignored for more than 50 years, using contemporary geochemical and mineralogical techniques to constrain the origins of two of the most well-known Mn oxide districts in the central and southern Appalachians.

\section{REGIONAL GEOLOGY AND FIELD RELATIONSHIPS}

We focused our study on the occurrence of Mn oxides within and near the foot of the Blue Ridge physiographic province in the Mountain City Window in northeastern Tennessee, and in the eastern Shenandoah Valley in northern Virginia. The stratigraphic interval that contains $\mathrm{Mn}$ oxide ores in our study area is the early Cambrian sediments, which are continuous throughout the central and southern Appalachians. The stratigraphic units include 1) the Erwin Formation and Antietam Sandstone (quartz sandstone and quartzite that comprises the upper part of the Chilhowee Group), 2) the Shady Dolomite and equivalent Tomstown Dolomite, and 3) the shales of the Rome Formation and equivalent Waynesboro Formation (see Table 1 for explanation of nomenclature).

Samples for this study were collected from within the Mountain City Window, a complex imbricate structure with early Cambrian sediments exposed below the Blue Ridge thrust fault (Figure 2). Samples were also collected from stratigraphically equivalent sediments from the Shenandoah Valley in northern Virginia at the foot of the Blue Ridge and from the footwall of the Blue Ridge thrust (Figure 3).

The stratigraphic and tectonic history of the Mountain City Window area has been described previously (Adams and Su, 1996; King and Ferguson, 1960; Merschat et al., 2014); the ore locations in this region are generally associated with earlier silica replacement of the Sh carbonate lenses within the Rome Formation, but are also found within the clay residuum of the Shady Dolomite, along

Table 1. Equivalent Cambrian sedimentary units of the southern and central Appalachians (Wilmarth, 1938).

\begin{tabular}{|c|c|c|}
\hline $\begin{array}{l}\text { northern } \\
\text { Virginia and } \\
\text { Pennsylvania }\end{array}$ & $\begin{array}{l}\text { Tennessee, } \\
\text { southwest } \\
\text { Virginia }\end{array}$ & $\begin{array}{l}\text { Georgial } \\
\text { Alabama }\end{array}$ \\
\hline $\begin{array}{l}\text { Waynesboro } \\
\text { Formation }\end{array}$ & $\begin{array}{l}\text { Rome Formation, } \\
\text { Watauga shale*, } \\
\text { Graysonton } \\
\text { formation* }\end{array}$ & $\begin{array}{l}\text { Rome Formation, } \\
\text { Cartersville } \\
\text { formation*, } \\
\text { Oostanaula shale* }\end{array}$ \\
\hline $\begin{array}{l}\text { Tomstown } \\
\text { Dolomite }\end{array}$ & Shady Dolomite & $\begin{array}{l}\text { Shady limestone*, } \\
\text { Jumbo Dolomite, } \\
\text { Beaver limestone* }\end{array}$ \\
\hline $\begin{array}{l}\text { Antietam } \\
\text { Sandstone } \\
\text { (upper part of } \\
\text { Chilhowee } \\
\text { Group) }\end{array}$ & $\begin{array}{l}\text { Erwin Formation } \\
\text { (upper part of the } \\
\text { Chilhowee Group) }\end{array}$ & $\begin{array}{l}\text { Weisner quartzite, } \\
\text { Chilhowee } \\
\text { sandstone* }^{\star}\end{array}$ \\
\hline
\end{tabular}



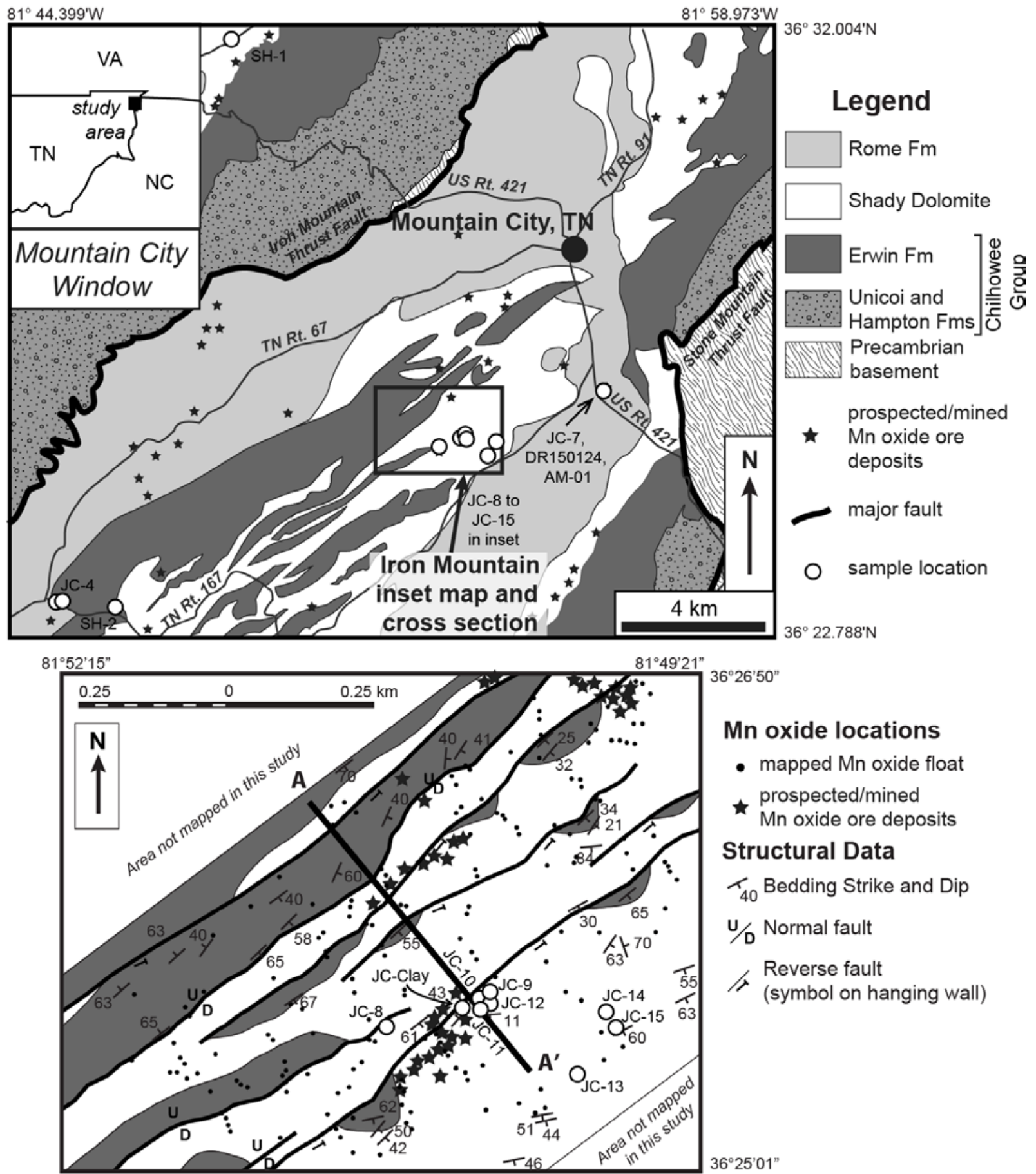

$36^{\circ} 26^{\prime} 50^{\prime \prime}$

Mn oxide locations

- mapped Mn oxide float

prospected/mined

Mn oxide ore deposits

\section{Structural Data}

$\widehat{T}_{40}$ Bedding Strike and Dip

U/ Normal fault

Reverse fault

(symbol on hanging wall)

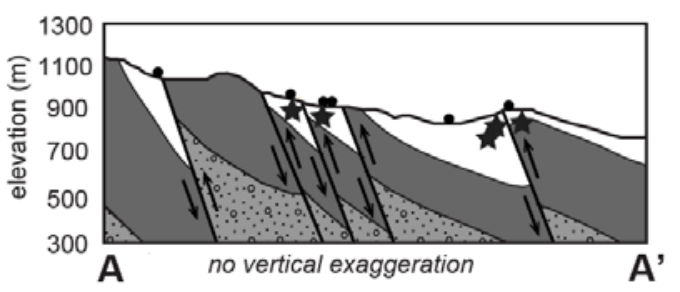

Figure 2. Map of the Mountain City Window in eastern Tennessee (top), after King and Ferguson (1960). Detailed inset map and cross section of the Doe Ridge Anticlinorium in the Mountain City Window (bottom), showing Mn oxide deposits along the hanging walls of reverse faults (modified from Rash et al., 2012), and Mn oxide float materials associated with jasperoid and clay residuum. 
bedding planes and joint surfaces in the Erwin Formation, and along high-angle, brittle faults within the Mountain City Window (Figure 2). These observations are consistent with those of King and Ferguson (1960); King et al. (1944); Rodgers (1945); Stose (1942); Stose and Schrader (1923). sandstone and orthoquartzite. Foose (1945) described these latter mineral forms as "psilomelane-type" minerals for localities investigated in southeastern Pennsylvania. Recent fieldwork has shown that areas with $\mathrm{Mn}$ oxides in concretionary forms occur near zones of deformed rock

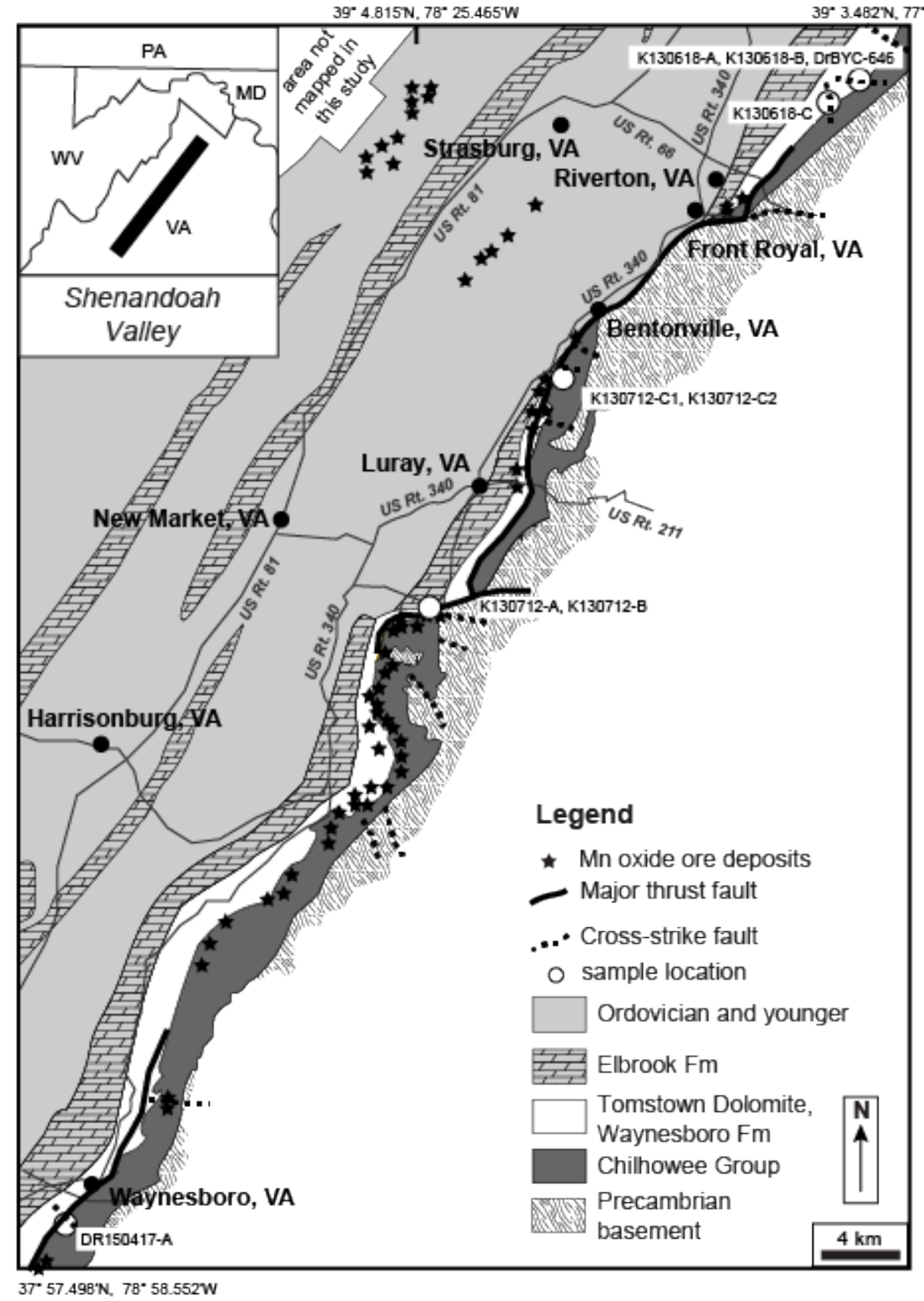

Figure 3. Map of the Shenandoah Valley region in northern Virginia, after Hack (1965).

The sampled Shenandoah Valley sites fall into two main categories: 1) concretionary masses of cryptocrystalline Mn oxide minerals that form in nodules within and replacing host sediments in shaly bedrock and highly weathered alluvial deposits, and 2) elongate and commonly radiating crystals of $\mathrm{Mn}$ oxide that form matrix cements in brecciated diffraction patterns were obtained on a JEOL JEM-1400 with a G-135 Pentafet Sealed Window X-ray detector at Appalachian State University. Major, trace and rare earth element geochemistry was performed at Activation Laboratories in Ancaster, Ontario (Canada) using the WRA+Trace 4 Lithoresearch analytical package. Principal 
component analysis (PCA) was performed on whole rock geochemical data using Past 3.12 (Hammer et al., 2001); all data were converted to elemental wt $\%$ and then arcsine transformed in Microsoft Excel.

Fluid inclusions in accessory jasperoid and quartz veins were analyzed on a USGS-type gas-flow heating and cooling stage with a Leitz Orthoplan petrographic microscope (equipped for both transmitted \& reflected light) at Virginia Tech. Fourier Transform Infrared Spectroscopy (FT-IR) analysis was performed at Appalachian State University on a Thermo Nicolet Magna 550 Spectrometer, using a $\mathrm{KBr}$ pellet press technique $(0.25 \%$ sample in $\mathrm{KBr}$ ) over a wavelength of $400-4000 \mathrm{~cm}^{-1}$.

\section{RESULTS AND DISCUSSION Field Distribution}

Appalachian Mn oxides have a spatial distribution that appears to have stratigraphic control, yet the deposits are not confined to any one rock unit. Instead, breccia deposits may be concentrated along high-angle, brittle faults between dolomite and quartzite (Figures 2, 3) or located within quartz sandstones along discrete fractured zones, while nodules are typically found in fine-grained deposits that are usually (but not always) associated with the weathered residuum of the Shady/Tomstown Dolomite or highly weathered alluvial materials. This distribution has likewise been noted in early economic mapping surveys (Harder, 1910; King et al., 1944; Miller, 1944; Stose, 1942; Stose and Miser, 1922; Stose et al., 1919; Stose and Schrader, 1923), and is not consistent with detrital or primary sedimentary origin for the deposits. Rather, the distribution suggests the Mn oxides formed due to late-stage fluid-rock interaction. The original Mn source has long been assumed to be the Mn-bearing carbonate minerals in the Shady/Tomstown Dolomite (Force and Cox, 1991; Rodgers, 1945), and most of the original work done in the Tennessee-Virginia region assumed that $\mathrm{Mn}$ oxide deposition was solely due to percolation and recirculation of Mn-rich groundwater through these units. However, some early prospecting work in Georgia (Kesler, 1941) and the Gossan Lead District in southwest Virginia (Jonas, 1942; Stose and Stose, 1957) did suggest hydrothermal fluids as an alternative $\mathrm{Mn}$ source.

\section{Sample Morphology}

$\mathrm{Mn}$ oxide morphologies from samples within the Mountain City Window study area are highly variable. For example, in a single $10 \mathrm{~m}^{2}$ outcrop of the Rome Formation known as the Shouns Prospect, Mn oxides are found within clay-rich residuum as nodules, but also form the matrix of silicic breccia deposits and are found as deposits along joints and bedding planes in intact rock (Figure 4A). In the fractures along existing bedding planes and joints in the Shouns Prospect, Mn oxides form matrix-supported fracture/breccia fill (Figure 4B) and wrinkled sheets up to 5 $\mathrm{mm}$ thick between bedding planes (Figure 4C). Morphologies of $\mathrm{Mn}$ oxides in breccias include thin drusy films partially covering the quartz in the geodes (Figure 4D), often with a rounded pellet of dull, black, compact Mn oxide found within the void, as well as porous and laminated deposits with interbedded Fe oxyhydroxide filaments and coatings (Figure 4E). Mn oxides can also form dendrites up to $3 \mathrm{~mm}$ in diameter (Figure 4F), three-dimensional branching structures ("shrubs") up to $5 \mathrm{~cm}$ in length (Figure 4G). Mn oxide nodules are usually botryoidal in shape and can be up to $10 \mathrm{~cm}$ in diameter (Figure $4 \mathrm{H}$ ), and often encase and replace the host sediments (Figure 4I). Large samples (diameter $>5 \mathrm{~cm}$ ) show growth extensions away from a central, layered zone. In the Iron Mountain region of the Mountain City Window (Figure 2, inset and cross section), interbedded Fe and Mn oxide deposits are found in the fractured axes of folds within the Shady Dolomite (Figure 5A) that are typically found near high-angle faults. These laminated $\mathrm{Fe}$ and $\mathrm{Mn}$ deposits contain both porous and compact layers (Figure 5B). In samples from the Erwin Formation, $\mathrm{Mn}$ and Fe oxides are located along bedding planes in quartzite (Figure 5C), or as delicate dendrites that coat fracture surfaces and have branches up to $1 \mathrm{~mm}$ across (Figure 5D).

In the Shenandoah Valley samples in northern Virginia, $\mathrm{Mn}$ oxides are found as either nodules in weathered residuum or as breccia matrices. Nodules are found in horizontal or shallowly dipping beds of weathered alluvium (Figures 6A, 6B), and show vein-like fractures that are composed of radiating crystals of cryptomelane and hollandite (Figure 6C) that cross-cut earlier manganese minerals encasing primary sedimentary grains of quartz, clays, and some (authigenic?) K-feldspars (mineralogy confirmed with SEM-EDS and X-ray diffraction, see following sections for details). Adjacent to these nodule deposits, brecciated Antietam Sandstone with $\mathrm{Mn}$ oxide coatings and weathered $\mathrm{Fe}$ oxyhydroxide matrix can be found along high angle cross-strike faults (Figure 6D). Regionally, breccias within the Antietam Sandstone are typically cemented by cryptocrystalline quartz; however, at several localities the cement is composed of dense, steely blue-gray Mn oxides (Figure 6E). These Mn cements exhibit a concentric layering (Figure 6F), and fill voids and fractures indicative of dilational failure. Reflected light microscopy shows thin shards and tiny breccia clasts of host quartz sandstone floating in the matrix of $\mathrm{Mn}$ oxide cement (Figure $6 G)$.

All sample data (morphology, mineralogy, location, stratigraphic association, mineral identification techniques, etc.) are provided in Data Repository File 1. 


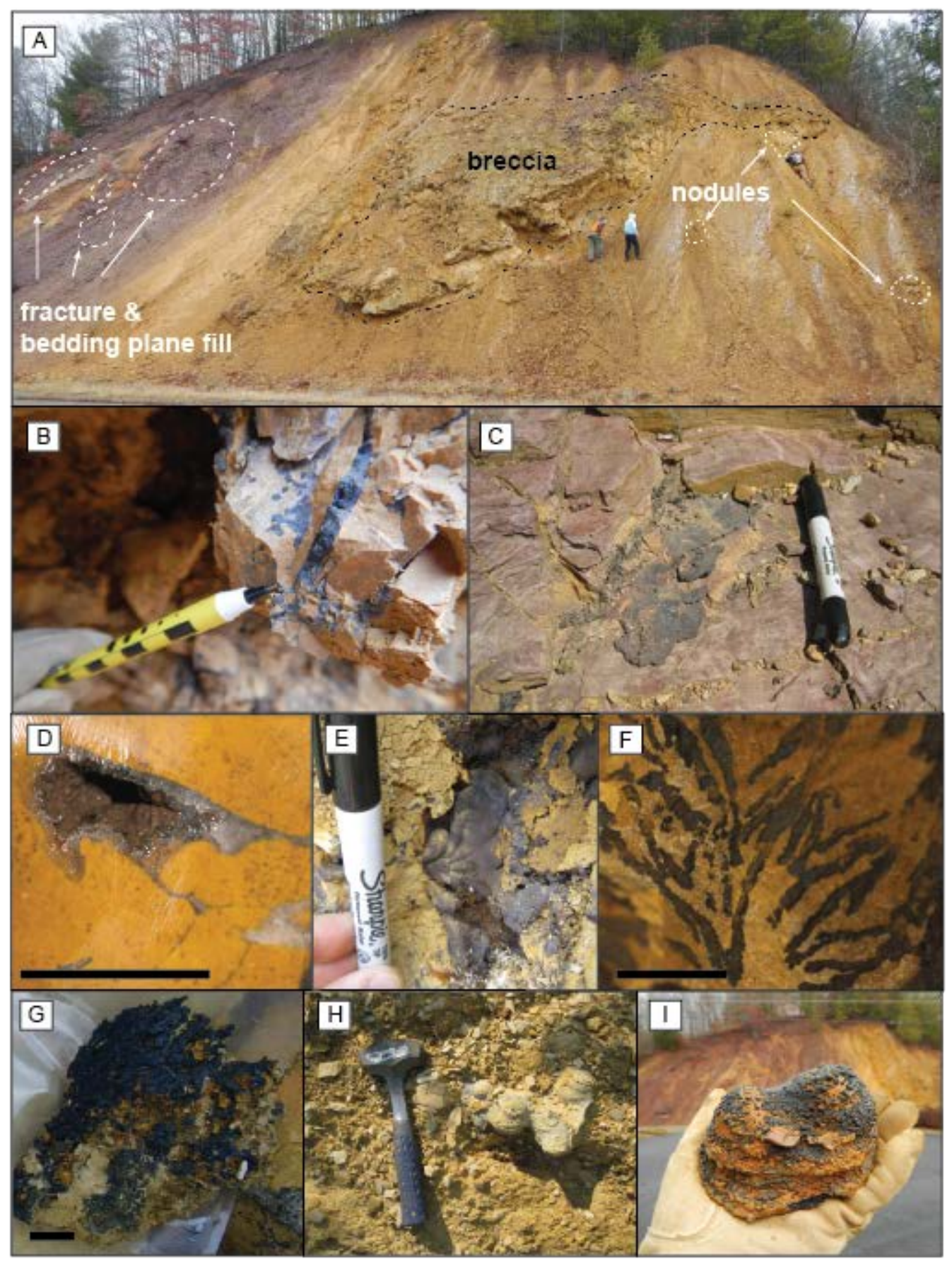

Figure 4. A) Eastern outcrop/roadcut of the Shady Dolomite and Rome Formation in the Shouns Prospect in the Mountain City Window, Tennessee showing zones of Mn oxidation within fracture and bedding planes, breccias, and nodules; B) matrix-supported fracture/breccia fill (sample DR150124-A1); C) fracture filling wrinkled sheets up to $5 \mathrm{~mm}$ thick (sample JC-7D); D) thin drusy films partially covering quartz in secondary geodes (sample JC-7A); E) porous and laminated deposits within breccia fill, with interbedded Fe oxyhydroxides; F) dendrites up to $3 \mathrm{~mm}$ in diameter on fracture surfaces (sample JC-7A); G) shrub structures up to $5 \mathrm{~cm}$ in length (sample JC-7C); H) in situ nodule within nodule-bearing sediments (sample JC-7B); I) nodules encase and replace host shaly bedrock, showing botryoidal nodule morphology. All scale bars $1 \mathrm{~cm}$. 


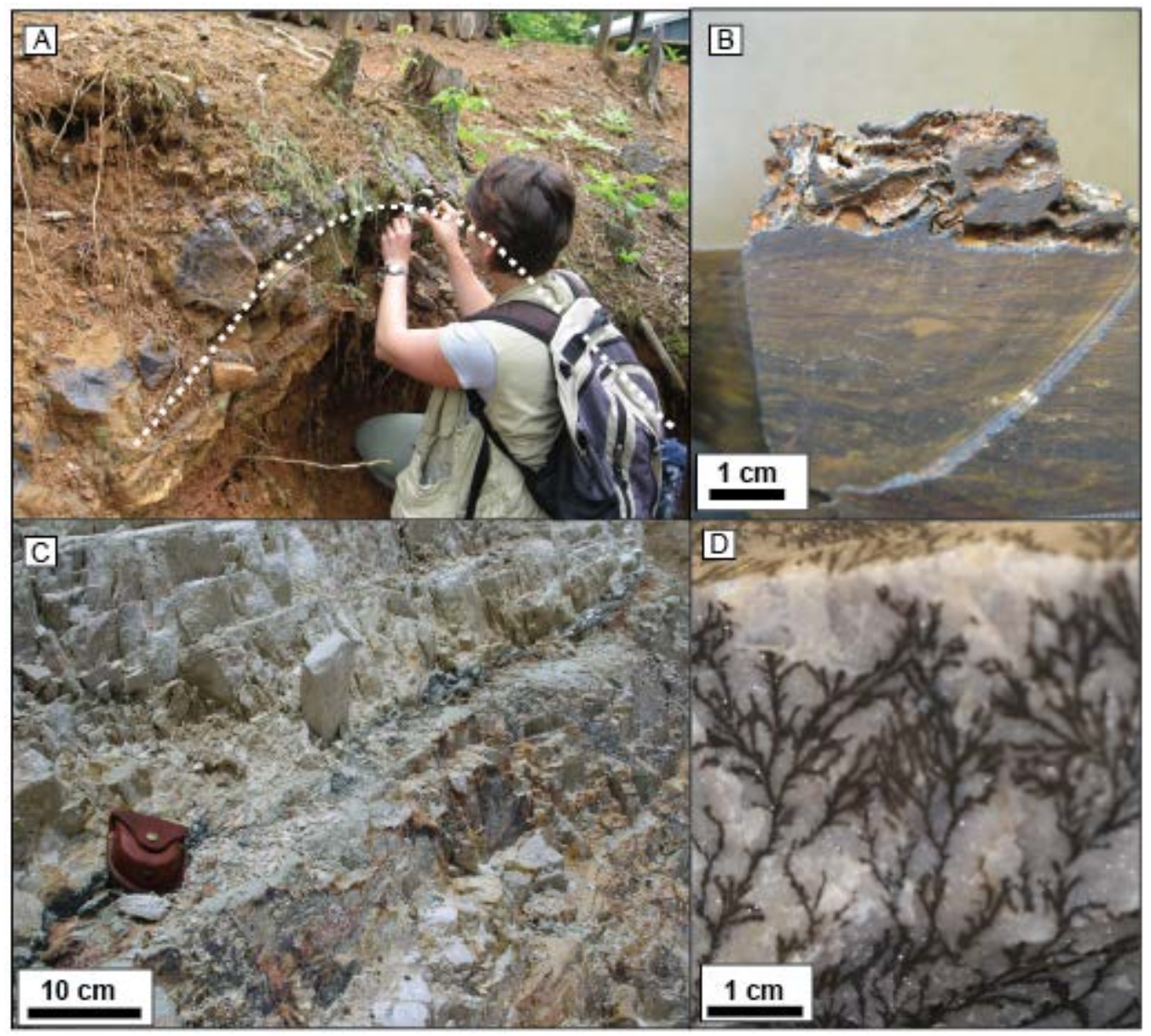

Figure 5. A) In the Shady Dolomite in the Iron Mountain location of the Mountain City Window of Tennessee, interbedded Fe and Mn oxide deposits are found in the fractured axes of existing folds; B) example of the interbedded Mn oxides and Fe oxyhydroxides showing porous and laminated morphologies (sample JC-10); C) in the Erwin Formation, Mn and Fe oxides are deposited along existing bedding planes in quartzite; and D) Mn oxides in the Erwin Formation are frequently deposited as dendrites up to $1 \mathrm{~mm}$ in diameter (sample $\mathrm{SH}-1$ ).

\section{Associated Rock Types}

In the Mountain City Window region, the breccias are strongly associated with zones of Cambrian carbonate host rock that have been replaced by silica of various forms, including jasper, chert, and drusy quartz. Outcrop and hand sample observations (Figures 5,6) as well as SEM imaging (see Electron Microscopy) all confirm that $\mathrm{Mn}$ oxide formation occurred subsequent to silica replacement of localized areas in the Shady Dolomite and of carbonate lenses in the Rome Formation. The association of Mn oxides with late-stage quartz mineralization is also apparent in the Erwin Formation samples (see Electron Microscopy). Interestingly, the high quality ores found in the Shenandoah Valley breccias are generally not associated with secondary quartz mineralization but instead show morphologies consistent with fluid-assisted brecciation and volume expansion (Figure 6), indicating changes in fluid pressure due to regional stresses (Jébrak, 1997). In contrast, the concretionary nodules we have examined from both locations are found in clay-rich residuum (Figures 4, 6) and are not associated with silica replacement, secondary quartz precipitation, or any obvious fluid pathways. Rather, the limited disruption of the clay layers surrounding the nodules (when fresh surfaces are visible in outcrop) and the preservation of primary sedimentary layering indicate that each nodule formed in place, encasing and dislocating the fine-grained particles of the host materials as it grew (Figures 4, 6).

\section{Electron microscopy - mineralogy and morphology Mountain City Window:}

SEM-EDS analyses coupled with X-ray diffraction (further discussed in X-ray and electron diffraction) indicate that the $\mathrm{Mn}$ oxide nodules from Mountain City Window sites consist of romanèchite, which has an ideal formula of $\mathrm{Ba} 0.66\left(\mathrm{Mn}^{4+}, \mathrm{Mn}^{3+}\right)_{5} \mathrm{O}_{10} \cdot 1.34 \mathrm{H}_{2} \mathrm{O}$. All other morphologies consist of a hollandite-cryptomelane solid solution (historically referred to as psilomelane), which has 
an ideal formula of $(\mathrm{Ba}, \mathrm{K})_{\times}\left(\mathrm{Mn}^{4+}, \mathrm{Mn}^{3+}\right)_{8} \mathrm{O}_{16}$, although there are considerable variations in its stoichiometry (Varentsov, 1996). Descriptions of $\mu \mathrm{m}$-scale sample mineralogy and morphology for Mountain City Window samples are provided in Table 2 and are shown in Figures 7-9. Breccia matrix samples include vermiform structures, dendritic meshes (with imprints of gas bubbles) containing $\mathrm{nm}$-scale Mn oxide needles, and irregular chains and interconnected clumps of
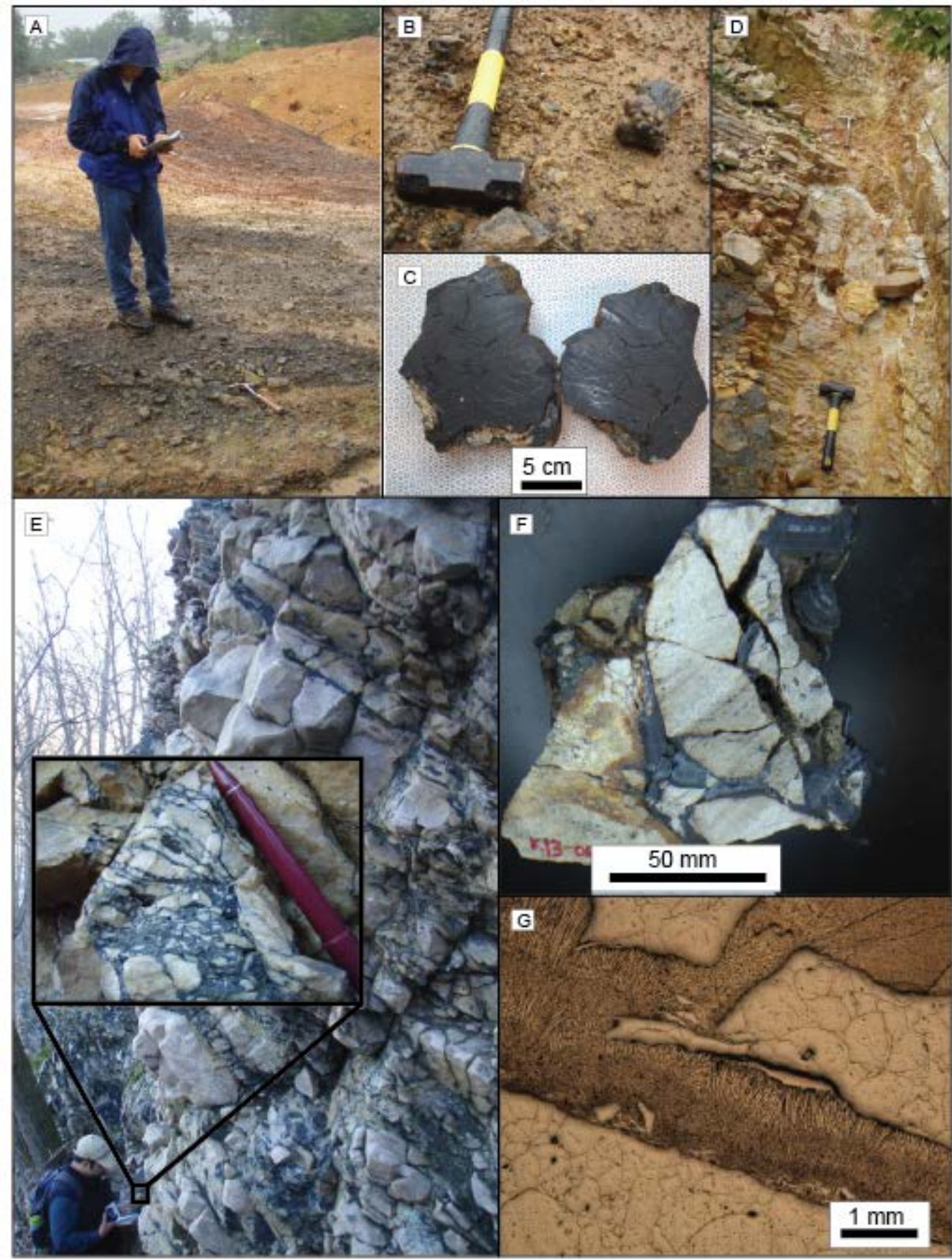

Figure 6. A) Horizontally-bedded layer of Mn oxide nodules within weathered alluvium at the Stanley prospect near Luray, Virginia in the Shenandoah Valley; B) Mn oxide nodules from the Stanley prospect; C) vein-like fractures show radiating crystals composed of secondary cryptomelane and hollandite (sample K13-07-12-B2); D) brecciated Antietam Sandstone with Mn oxide coatings and weathered Fe oxyhydroxide matrix along a high angle cross-strike fault located adjacent to the deposit of nodules; E) outcrop of brecciated Antietam Sandstone cemented by $\mathrm{Mn}$ oxides along the bluffs of the Shenandoah River northeast of Front Royal, Virginia, with inset showing close-up view of brecciated Antietam Sandstone (light colored) cemented by Mn oxide (dark color) with pencil for scale (sample DRBYC-646); F) hand sample of brecciated Antietam Sandstone with concentrically-layered Mn oxide as a matrix cement (sample K13-06-18C); G) reflected light photomicrograph of quartz sandstone breccia cemented by Mn oxide - note the thin shards and tiny breccia clasts of quartz floating in the matrix cement (sample K13-06-18B). 
Table 2. Description of mineralogy and mineral morphologies seen in hand sample and via scanning electron microscopy.

\begin{tabular}{|c|c|c|c|c|}
\hline Location & $\begin{array}{l}\text { Mn oxide } \\
\text { morphology }\end{array}$ & Mineralogy & SEM textural observations & $\begin{array}{l}\text { Representative } \\
\text { Figures }\end{array}$ \\
\hline \multirow[t]{7}{*}{$\begin{array}{l}\text { Mountain City } \\
\text { Window, TN }\end{array}$} & dendrites & $\begin{array}{l}\text { hollandite- } \\
\text { cryptomelane solid } \\
\text { solution }\end{array}$ & $\begin{array}{l}\text { nm-scale Mn oxide needles } \\
\text { forming microporous and irregular } \\
\text { sheets with imprints of gas bubbles }\end{array}$ & 4F, 5D, 7A, 7B \\
\hline & $\begin{array}{l}\text { pellets within } \\
\text { geodes }\end{array}$ & $\begin{array}{l}\text { hollandite- } \\
\text { cryptomelane solid } \\
\text { solution, } \\
\text { montmorillonite }\end{array}$ & $\begin{array}{l}\text { irregular chains and interconnected } \\
\text { clumps of acicular Mn oxide } \\
\text { needles radiating from } \\
\text { montmorillonite clay spheres }\end{array}$ & 4D, 7C, 7D \\
\hline & $\begin{array}{l}\text { drusy on geode } \\
\text { interior }\end{array}$ & $\begin{array}{l}\text { hollandite- } \\
\text { cryptomelane solid } \\
\text { solution, } \\
\text { montmorillonite }\end{array}$ & $\begin{array}{l}\text { irregular chains and interconnected } \\
\text { clumps of acicular Mn oxide } \\
\text { needles radiating from } \\
\text { montmorillonite clay spheres }\end{array}$ & 4D, 7C, 7D \\
\hline & shrubs & $\begin{array}{l}\text { hollandite- } \\
\text { cryptomelane solid } \\
\text { solution; goethite }\end{array}$ & $\begin{array}{l}\text { radiating, oriented } \mu \text { m-scale } \\
\text { columns with square cross } \\
\text { sections; intergrown with gravity- } \\
\text { draped vermiform structures and } \\
\text { networks/meshes of goethite- } \\
\text { encrusted tubular filaments }\end{array}$ & $\begin{array}{l}4 \mathrm{E}, 4 \mathrm{G}, 8 \mathrm{~A}, 8 \mathrm{~B}, 8 \mathrm{C}, \\
8 \mathrm{D}, 8 \mathrm{E}\end{array}$ \\
\hline & fracture fills & $\begin{array}{l}\text { hollandite- } \\
\text { cryptomelane solid } \\
\text { solution }\end{array}$ & $\begin{array}{l}\text { root-like anastomosing stringers of } \\
\text { oriented } \mu \mathrm{m} \text {-scale columns with } \\
\text { square cross sections that radiate } \\
\text { out from nucleation sites in } \\
\text { increasing diameter }\end{array}$ & $4 \mathrm{~B}, 4 \mathrm{C}, 5 \mathrm{C}, 7 \mathrm{E}, 7 \mathrm{~F}$ \\
\hline & $\begin{array}{l}\text { concretionary } \\
\text { nodules }\end{array}$ & $\begin{array}{l}\text { romanèchite, quartz, } \\
\text { Ba-rich orthoclase }\end{array}$ & $\begin{array}{l}\text { crumpled sheets of Mn oxide } \\
\text { surrounding silt particles (quartz, } \\
\text { K-feldspar) }\end{array}$ & $4 \mathrm{H}, 4 \mathrm{I}, 9 \mathrm{~A}, 9 \mathrm{~B}$ \\
\hline & $\begin{array}{l}\text { internally layered } \\
\text { breccia matrices }\end{array}$ & romanèchite, goethite & $\begin{array}{l}\text { concentrically layered Mn oxide } \\
\text { sheets intergrown with filaments } \\
\text { encrusted with goethite }\end{array}$ & $5 B, 9 C, 9 D$ \\
\hline \multirow[t]{2}{*}{ Shenandoah Valley } & $\begin{array}{l}\text { concretionary } \\
\text { nodules }\end{array}$ & $\begin{array}{l}\text { hollandite and } \\
\text { cryptomelane (not } \\
\text { solid solution), } \\
\text { lithiophorite, detrital } \\
\text { silicates }\end{array}$ & $\begin{array}{l}\text { concentric rings of separate } \\
\text { hollandite and cryptomelane layers } \\
\text { surrounding lithiophorite and } \\
\text { detrital silicates/clays; nodules also } \\
\text { have interior vugs with acicular } \\
\text { cryptomelane needles }\end{array}$ & $\begin{array}{l}6 \mathrm{~A}, 6 \mathrm{~B}, 6 \mathrm{C}, 10 \mathrm{~A} \\
10 \mathrm{~B}, 10 \mathrm{C}, 10 \mathrm{D}\end{array}$ \\
\hline & breccia matrices & $\begin{array}{l}\text { hollandite and } \\
\text { cryptomelane (not } \\
\text { solid solution) }\end{array}$ & $\begin{array}{l}\text { hollandite and cryptomelane } \\
\text { needles and layers, forming } \\
\text { concentric rings }\end{array}$ & $\begin{array}{l}6 \mathrm{D}, 6 \mathrm{E}, 6 \mathrm{~F}, 6 \mathrm{G} \\
11 \mathrm{~A}, 11 \mathrm{~B}, 11 \mathrm{C} \\
11 \mathrm{D}, 11 \mathrm{E}, 11 \mathrm{~F}\end{array}$ \\
\hline
\end{tabular}

acicular nm-scale $\mathrm{Mn}$ oxide needles radiating from montmorillonite clay spheres (Figure 7). Many Mn oxide samples show microcrystalline nucleation sites for larger, radiating crystals (Figures 7E, 7F, 8), and FIB-EM longitudinal milling of goethite filament meshes likewise shows microporous cylindrical voids $<1 \mu \mathrm{m}$ in diameter surrounded by concentric rings of goethite, also indicating microcrystalline nucleation sites (Figures 8C, 8D, 8E). Regardless of hand sample morphology, breccia samples within the Mountain City Window show nucleation sites for all of the $\mathrm{Mn}$ and Fe oxide crystals that consist of undulating and irregular planes, draped vermiform/filamentous structures, chains of clay spheres, and/or networked filament meshes. In contrast, nodule samples consist of microcrystalline, crumples sheets of romanèchite enveloping silt particles (Figure 9).

Spot TEM-EDS analysis of individual crystals from shrubs and dendrites indicated an average $\mathrm{Ba} / \mathrm{K}$ ratio of approximately 2.93 (with a range of $0.99-5.96$ ). This is in contrast to earlier work on a variety of $\mathrm{Mn}$ oxide dendrites by Xu et al. (2010), which found that dendrites are primarily composed of a single phase (typically birnessite). SEM-EDS analysis of breccia matrix samples also shows $\mathrm{Ba} / \mathrm{K}$ ratios within this range for hollandite-cryptomelane solid solutions. TEM spot analysis indicates that the romanèchite approaches its ideal formula of

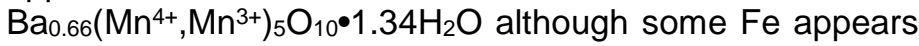
to be substituting for the $\mathrm{Mn}$ (data provided in DR File 2).

\section{Shenandoah Valley:}

Mn oxide samples from the Shenandoah Valley differ somewhat from those in the Mountain City Window (Table 2, Figures 10-11). Whereas botryoidal nodules in the Mountain City Window are all composed of romanèchite sheets, nodules in the Shenandoah Valley are composed of microcrystalline hollandite-cryptomelane aggregates (not in 


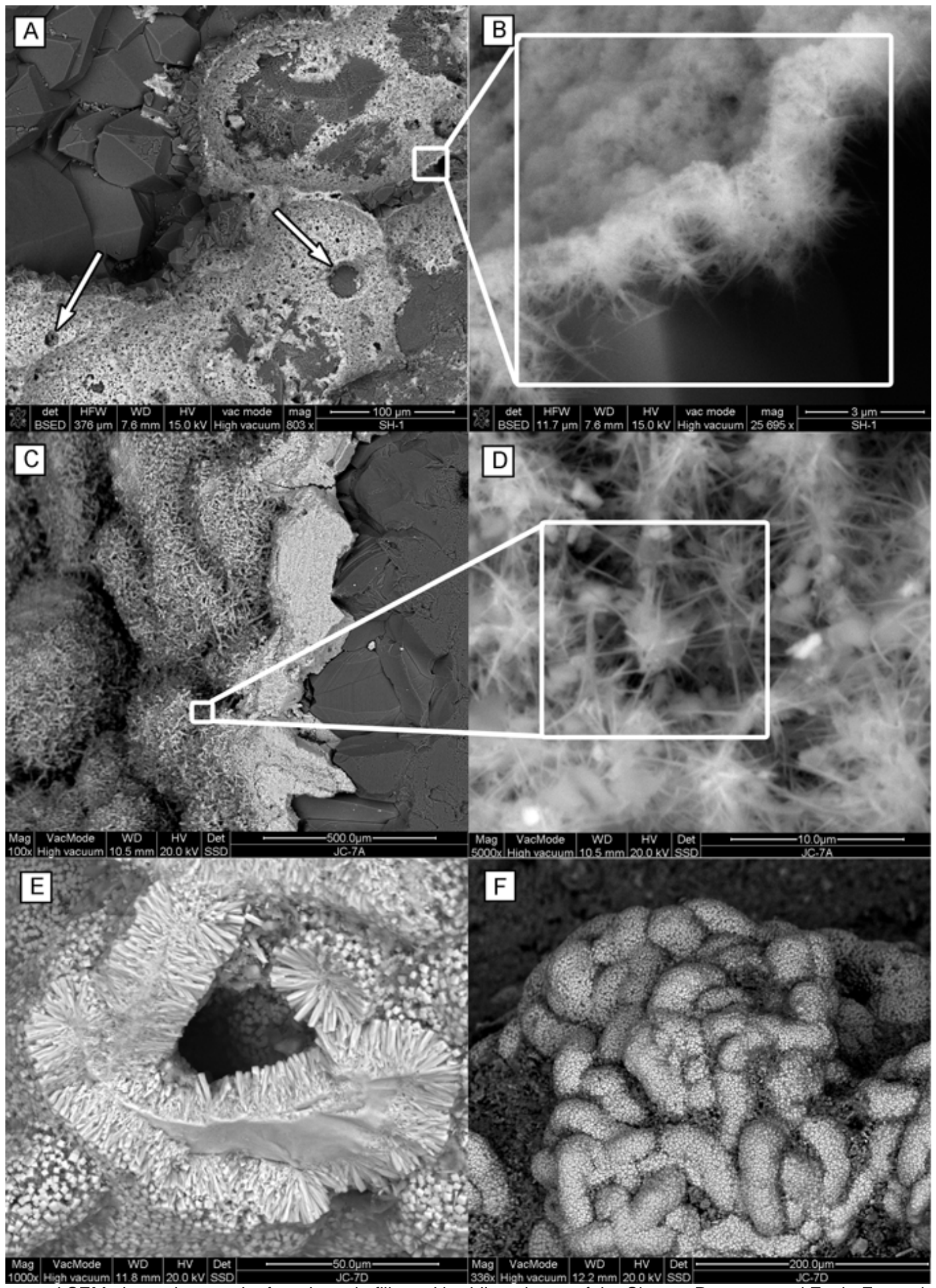

Figure 7. Backscattered SEM photomicrographs from breccia fills and bedding planes of the Shouns Prospect and Erwin Formation showing A) surface of Erwin Formation sample SH-1 (hand sample shown in Figure 5D) with Mn oxide dendrites (white mineral) surrounded by a rind of secondary quartz (gray) with imprints of gas bubbles (white arrows); B) a porous network of nm-scale needles of a solid solution of cryptomelanehollandite that form the dendrite shown in Figure $7 \mathrm{~A} ; \mathrm{C}$ ) drusy coating of cryptomelane-hollandite Mn oxides on the interior surfaces of quartz geodes in Shouns Prospect sample JC-7A (hand sample shown in Figure 4D), forming a network of interconnected strings of Mn oxide needles; D) chains of $\mathrm{Mn}$ oxide needles showing acicular radiation from strands of montmorillonite clay spheres that form the interconnected strings shown in Figure 7C; E) Shouns Prospect sample JC-7D (field photo shown in Figure 4C) showing porous and anastomosing root-like structures of hollanditecryptomelane columns with square cross sections, showing increases in size from nucleation sites; F) rounded and interwoven lumps of hollanditecryptomelane columns, also from Shouns Prospect sample JC-7D. 


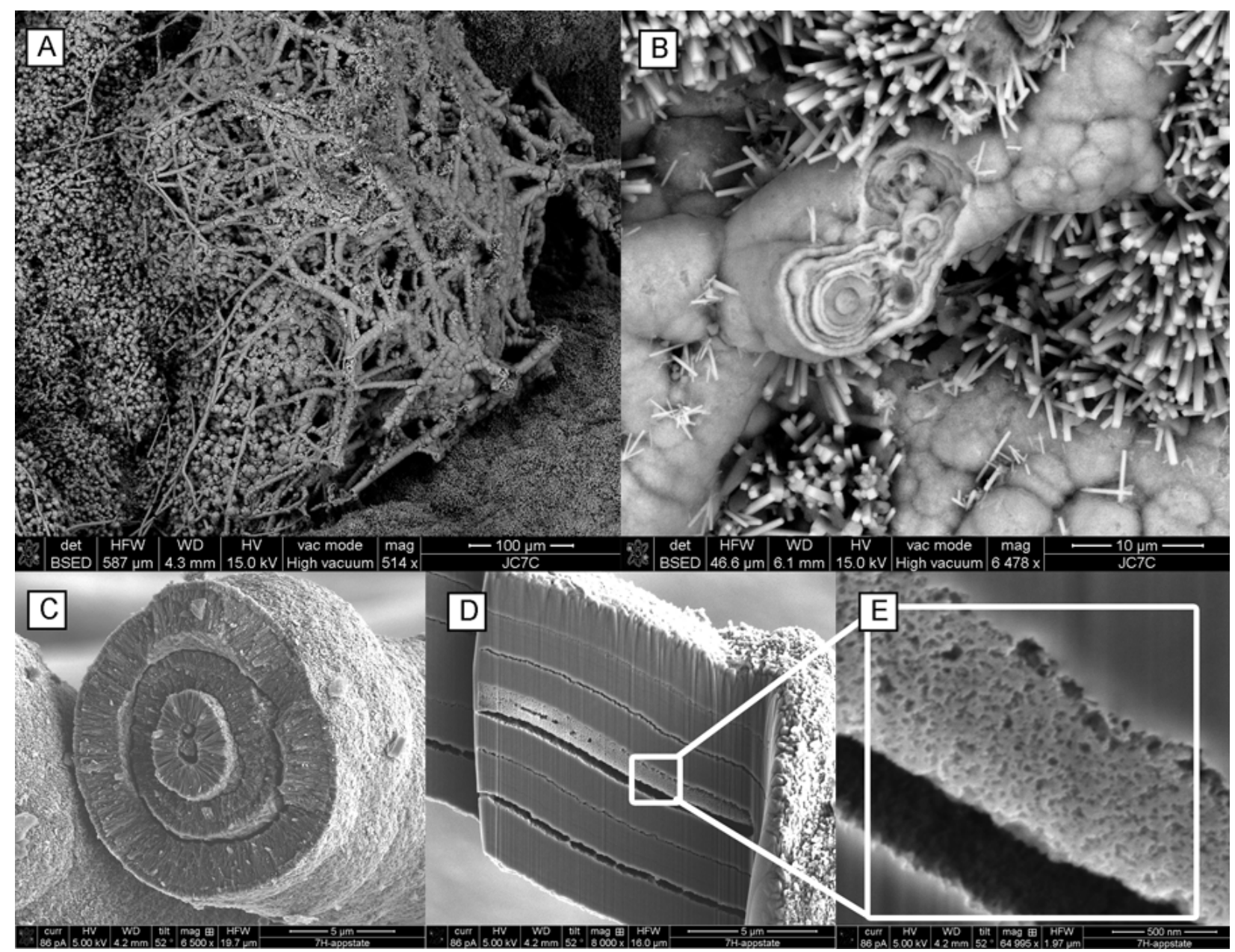

Figure 8. A) Backscattered SEM image showing gravity draping of goethite within shrub structures in breccia fills from sample JC-7C of the Shouns Prospect in the Mountain City Window (hand sample shown in Figure 4G); B) close-up of goethite filaments in shrub structures surrounded by of hollandite-cryptomelane columns; C) FIB-EM image of goethite-encrusted filaments of sample JC-7H of the Shouns Prospect; D) FIB-EM image of goethite structure in $\mathrm{JC}-7 \mathrm{H}$ with longitudinal sectioning via FIB ablation showing with $\mathrm{nm}$-scale, microcrystalline, porous interiors; E) interior of ablated goethite filament shown in Figure 8D.

solid solution) that surround lithiophorite grains as well as detrital silicates (Figure 10A, 10B). These nodules also contain interior vugs with acicular cryptomelane needles (Figure 10C) and have secondary veins of pure cryptomelane needles cross-cutting the more heterogeneous nodule material (Figure 10D). Breccia matrices of the Shenandoah Valley samples are likewise composed of hollandite-cryptomelane needles and layers (Figure 11). However, in general individual crystals are much larger (up to $200 \times 10 \mu \mathrm{m}$ ) and $\mu \mathrm{m}$-scale variations in the $\mathrm{Ba} / \mathrm{K}$ ratio within and among these radiating crystals is readily apparent in both BSE images and EDS spectra (DR File 2). The layers of alternating cryptomelane and hollandite also exhibit variations in microporosity (Figure $11 B)$, as well as unusual "sunflower" morphologies of nucleated concentric cryptomelane layers with radiating hollandite blades (Figures 11C, 11D). The breccia matrix material exhibits a concentric layering visible in both hand sample and reflected light (Figures 6F, 6G) as well as backscattered SEM imaging (Figures 11E, 11F) where the cement is composed of well-formed crystals of cryptomelane (darker gray) and hollandite (lighter gray). Although the dominant $\mathrm{Mn}$ oxide phase in both the nodules and breccias is hollandite-cryptomelane, locally these breccia matrix minerals can also be enriched in $\mathrm{Co}$, and rare lithiophorite is found in some samples (DR File 2).

\section{X-ray and electron diffraction}

Powder and single-crystal micro-X-ray diffraction patterns indicate that on both the macro- and micro-scales, all Mountain City Window $\mathrm{Mn}$ and Fe oxide samples are highly crystalline, with sharp and well-defined peaks (Figure 12), which is confirmed by sharp electron diffraction patterns from single crystals (Figure 13). In addition, TEM images of the dendrites, shrubs, drusy coatings, pellets, and laminae from Mountain City Window samples show $\sim 7 \AA$ lattice fringes corresponding to a (110) d-spacing (center crystal) and a (100) d-spacing (left crystal) of the hollandite group 

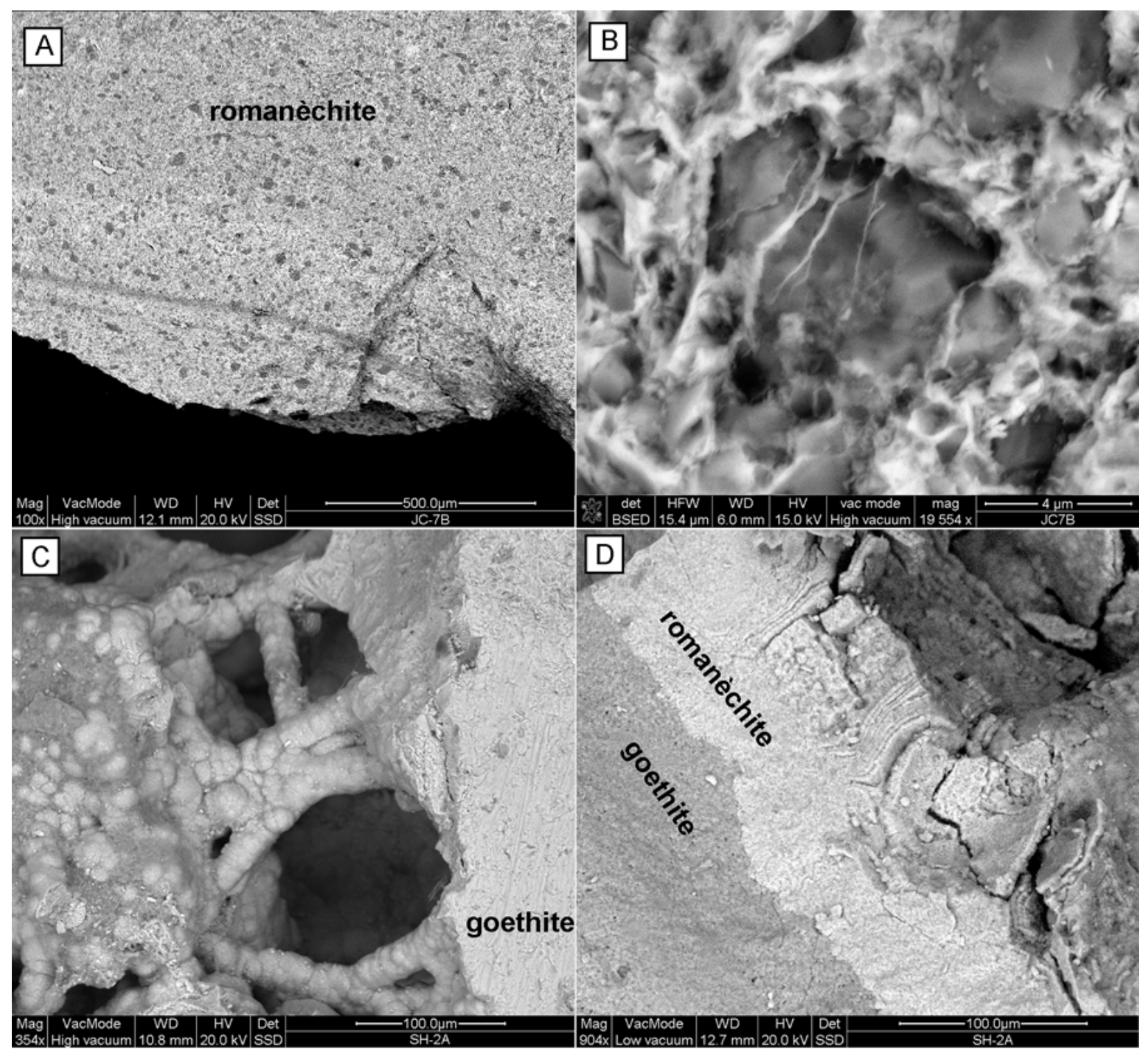

Figure 9. Backscattered SEM images of $A$ ) romanèchite nodule sample JC-7B from the Shouns Prospect of the Mountain City Window (as seen in Figure $4 \mathrm{H}$ ); B) enlarged image of (A) showing cracked, angular Ba-rich orthoclase (dark gray) encased in romanèchite (white) sheets; breccia matrix of sample SH-2 from the Erwin Formation showing $\mathrm{C}$ ) goethite-coated filaments and $\mathrm{D}$ ) micro-layered romanèchite interbedded with goethite.

minerals (Figure 13). Powder X-ray diffraction patterns (Figure 12) show that breccia matrix Mn oxides from both the Mountain City Window samples and the Shenandoah Valley samples are comprised of nearly pure and highly crystalline cryptomelane-hollandite, consistent with both optical and electron petrography. Interestingly, the mineralogy of the Shenandoah Valley nodules is similar to the Mountain City breccia matrices, but not the Mountain City nodules. As expected, detrital quartz is also present in both sets of nodules. The wide breadth of all peaks attributed to hollandite-cryptomelane suggests a very fine crystallite size (again consistent with electron petrography).

\section{Whole Rock Geochemistry General trends}

Whole rock geochemical patterns within the ores are somewhat variable (data are provided in DR File 3 ), but principal component analysis plots (Figure 14) of samples with more than $30 \mathrm{wt}$ \% MnO show noticeable differences between units (Mountain City Window breccias, Mountain City Window nodules, Shenandoah Valley breccias, and Shenandoah Valley nodules). For example, Shenandoah Valley breccia matrix samples are higher in $\mathrm{Ba}$ than Shenandoah Valley nodules, and Mountain City Window nodules have distinctly higher $\mathrm{Si} / \mathrm{Fe} / \mathrm{Al} / \mathrm{Pb} / \mathrm{K}$ and $\mathrm{Ba}$ contents than Shenandoah Valley nodules. This difference 


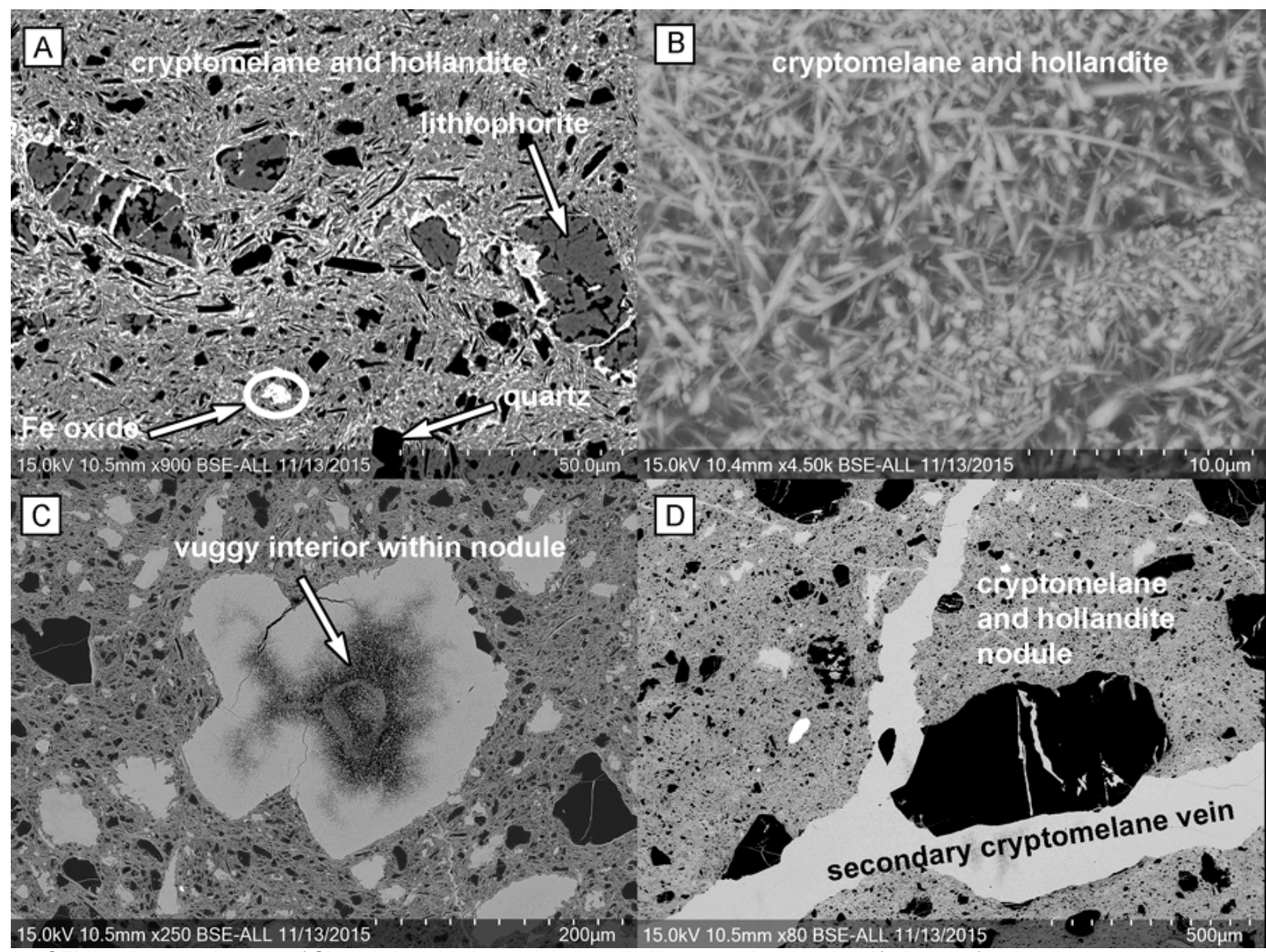

Figure 10. SEM backscatter images of Shenandoah Valley nodule sample K13-07-12B2 showing A) sheets of hollandite-cryptomelane surrounding lithiophorite, Fe oxides, clays, and quartz; B) close up of cryptomelane and hollandite needles; C) nodule with interior vugs filled with hollanditecryptomelane needles; D) secondary veins of cryptomelane cross-cutting nodules.

in nodule chemistry may be due to the presence of Ba-rich authigenic K-feldspars entrained in the Mountain City Window nodules (Figures 12, 9A, 9B). The remaining Mountain City Window breccia samples retain a high degree of geochemical scatter. PCA data for Figure 14 are provided in DR File 4. PCA plots and loadings using the full suite of sample data (including the two samples with < $1 \mathrm{wt}$. \% MnO due to significant quartz or goethite content) show that the amount of $\mathrm{Mn}$ and $\mathrm{Ba}$ (PC1) accounts for $88.8 \%$ of the variance in the system (DR Figure 1), and simply reflect the major element mineralogy of each sample.

\section{Geochemical associations}

Using the geochemical association signatures and diagnostic plots of Nicholson (1992), we attempted to constrain the source fluids responsible for the Mn oxide precipitation, but found much ambiguity in the results. For example, the Appalachian manganese ores plot with a fresh water (vs. sea water) origin when comparing major elements such as $\mathrm{Na}$ and $\mathrm{Mg}$ (Figure 15A). However, when comparing trace element signatures in a diagnostic plot of $(\mathrm{Co}+\mathrm{Ni}) \mathrm{vs}$.
$(\mathrm{As}+\mathrm{Cu}+\mathrm{Mo}+\mathrm{Pb}+\mathrm{V}+\mathrm{Zn})$, most plot with a hydrothermal mineralization signature (Figure 15B) vs. precipitation directly from the water column (in either marine or fresh waters). When comparing trace elements such as $\mathrm{Zn}$ and $\mathrm{Pb}$ to further constrain the source fluid, it is clear that no Appalachian ore samples plot in the dubhite (weathered mineral deposit) category (Figure 15C).

As nearly all the deposits contain $>15,000 \mathrm{ppm} \mathrm{Ba}$, but $<0.2$ wt. \% Na, <206 ppm Zr, <12 ppm Mo, <670 ppm Cu, $<670 \mathrm{Ni}$, and $<276 \mathrm{ppm} \mathrm{Y}$, their average composition best fits a fresh water fluid source as described in Nicholson (1992). However, this fresh water designation does not differentiate fresh water precipitation from a surface water body vs. terrestrial groundwater interactions with a previous hydrothermal deposit (i.e. supergene alteration). A comparison of the standard geochemical enrichment signatures of Nicholson (1992) supports this duality where samples best fit within the field of a supergene terrestrial source (Figure 16). The extremely high amount of $\mathrm{Ba}$ in the Appalachian ore samples would seem to indicate that both hydrothermal and supergene terrestrial fluids are equally 


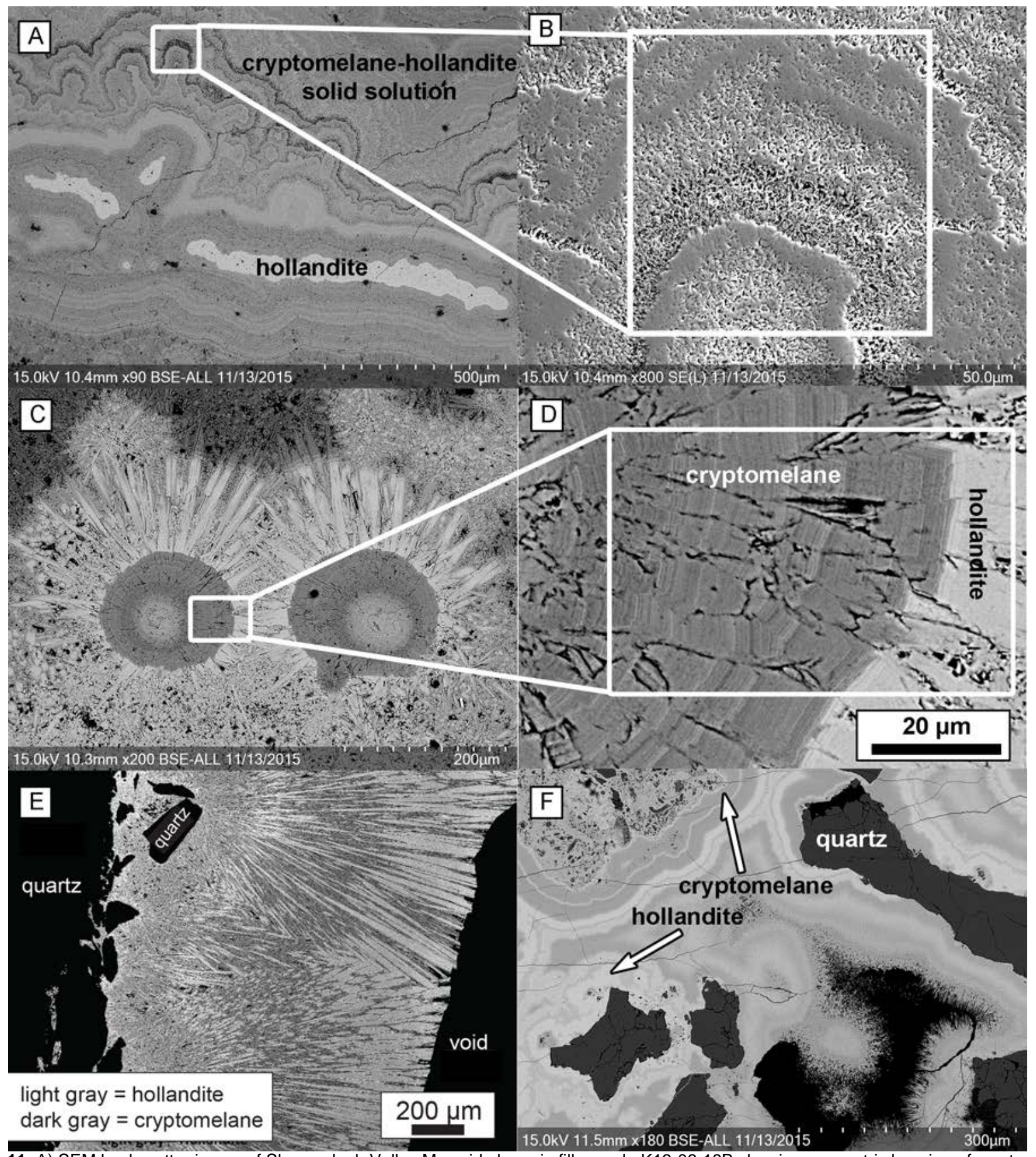

Figure 11. A) SEM backscatter image of Shenandoah Valley Mn oxide breccia fill sample K13-06-18B showing concentric layering of cryptomelane and hollandite minerals; B) SEM secondary electron image of needle-like forms of the minerals in growth layers of Figure 11A; C) SEM backscatter image of breccia matrix in sample K13-06-18B showing "sunflowers" of radiating crystals of cryptomelane and hollandite; D) high-magnification of a portion of Figure $11 \mathrm{C}$ showing concentric growth layers of the Mn oxides and compositional layering between the K-and Ba-bearing end members; E) SEM backscatter image of Shenandoah Valley breccias showing interfingering between hollandite and cryptomelane blades growing from a quartz substrate into a void; F) Mn oxide breccia matrix sample DR150417-B showing concentric layering of cryptomelane and hollandite around quartz crystals and mixed Mn oxide phases. 


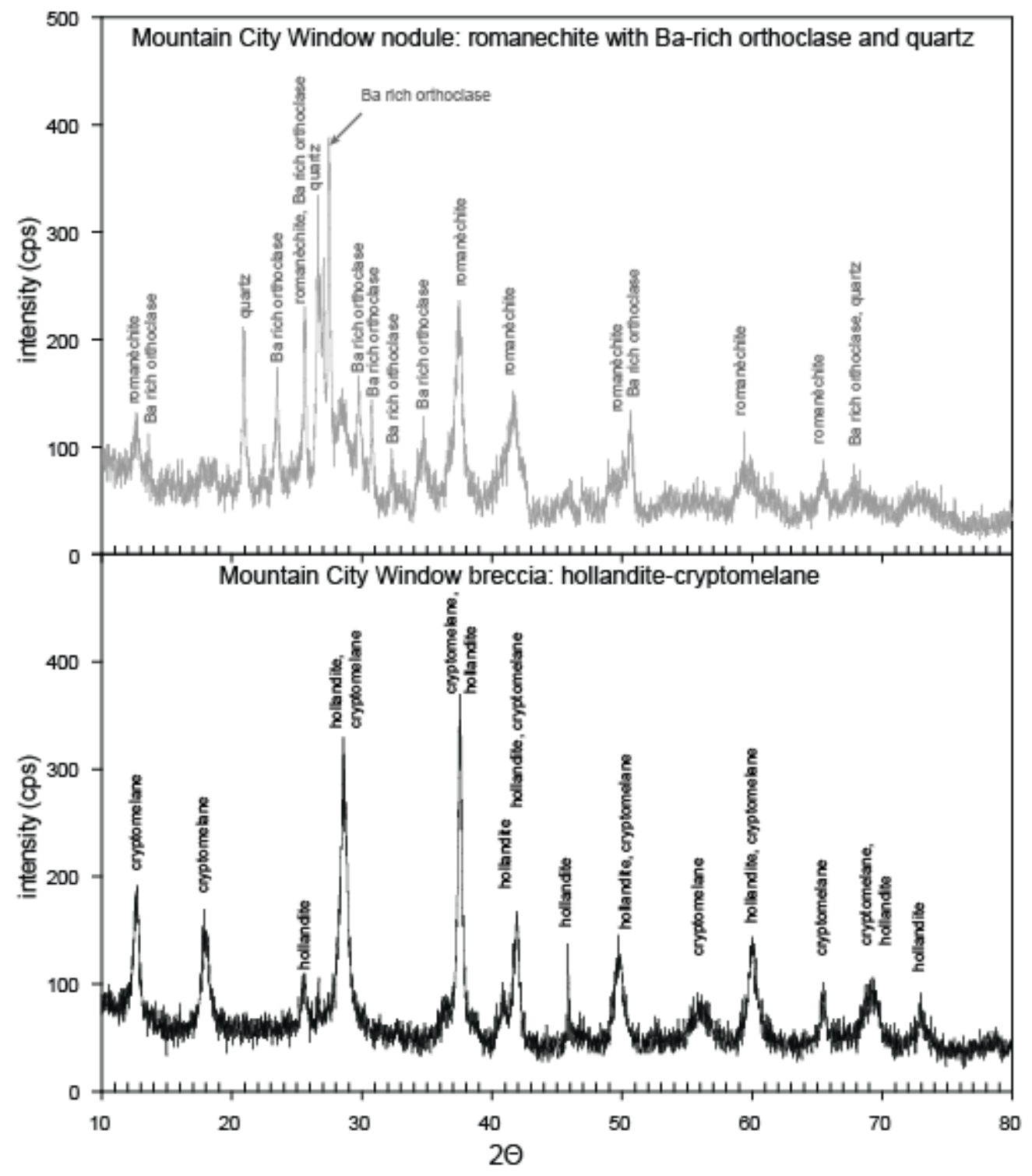

Figure 12. Powder XRD patterns of nodule JC-7B showing somewhat sharp peaks of romanèchite mixed with quartz and Ba rich orthoclase (top), while nearby breccia matrix material in sample JC-7C shows hollandite-cryptomelane solid solutions (bottom). Both samples are from the Shouns Prospect in the Mountain City Window.

likely as fluid sources (their plots are nearly identical), while removal of the $\mathrm{Ba}$ component from the hydrothermal enrichment category shows the contribution of the other diagnostic hydrothermal elements (As, $\mathrm{Cu}, \mathrm{Li}, \mathrm{Mo}, \mathrm{Pb}, \mathrm{Sb}$, $\mathrm{Sr}$, and $\mathrm{V})$. Although a supergene marine source would appear to be feasible for the Mountain City Window nodules according to Figure 16, the presence of Ba-rich authigenic K-feldspar within the nodules (Figures 12, 9A, 9B) and the presence of cryptomelane in the breccia samples (most often associated with surface weathering) would artificially inflate these values. K-feldspar particles in the Mountain City
Window nodules are classified as authigenic due to their angular morphologies (Figure $9 \mathrm{~B}$ ) and their $\mathrm{K} / \mathrm{Rb}$ ratio that ranges from 773-793, compared to ratios of $<440$ for a detrital K-feldspar from an igneous source (Hearn et al., 1987) or < 300 for a metamorphic source (Whitney, 1969).

Although field relationships and geochemical signatures indicate a hydrothermal or supergene origin for the fluids that deposited the $\mathrm{Mn}$ oxides in this study, the original source of the $\mathrm{Mn}$ and $\mathrm{Ba}$ prior to fluid remobilization remains unknown. The coupling of $\mathrm{Ba}$ and $\mathrm{Mn}$ has been used to describe primary $\mathrm{Mn}$ oxide precipitation in a euxinic marine 
basin environment (Maynard, 2010), but recent reevaluations of the paleoenvironments of the host sediment sequences (the Shady/Tomstown Dolomite, Erwin/Antietam Sandstone, and Rome/Waynesboro Formation) do not find any evidence for early Paleozoic anoxic basins in the study areas (Hageman and Miller III, 2016; Smoot and Southworth, 2014). The source of the $\mathrm{Ba}$ is unclear, but Mississippi Valley Type (MVT) hydrothermal ore deposits containing barite are known throughout the Cambrian sediments of the central and southern Appalachains (Kesler et al., 1997 and references therein) and many of these locations either partially or completely overlap with the Mn oxide ore locations described throughout the cental

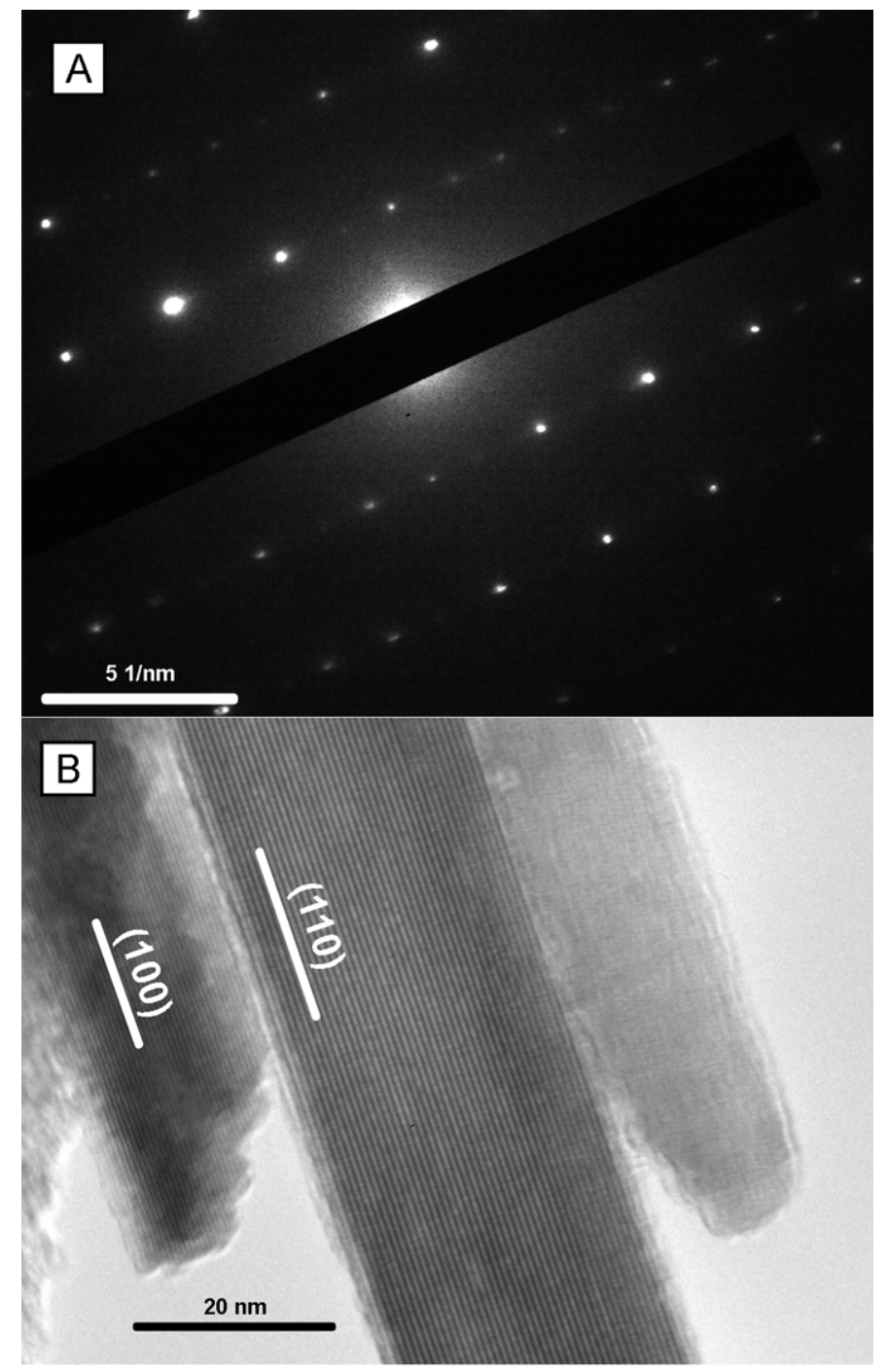

Figure 13. A) TEM electron diffraction pattern of cryptomelanehollandite blade from breccia matrix sample in Mountain City Window indicating a high degree of crystallinity; B) TEM image of cryptomelanehollandite needles from Mountain City Window dendrite sample showing $\sim 7 \AA$ lattice fringes corresponding to a (110) d-spacing of the hollandite group minerals (center crystal), and $\sim 5 \AA$ lattice fringes corresponding to a (200) d-spacing (left crystal, showing (100) plane traces in image due to reflections with other smaller crystals).
Appalachians (Figure 1). Therefore, while all samples are generally consistent with a supergene terrestrial fluid source, it is very possible that they represent multiple generations of dissolution and recrystallization of earlierformed hydrothermal $\mathrm{Mn}$ bearing minerals.

$\mathrm{Th}, \mathrm{Nb}$, and $\mathrm{Y}$ contents were used to parse out additional geochemical differences within fresh water systems (Figure 17), as the high field strength elements show differences between karst-hosted, sedimentary-hosted, and volcanichosted deposits (Maynard, 2010). Although a karst-hosted origin can be eliminated for all of the samples in this study, there is too much overlap between the other reference units to make any further determinations using this method. These signatures support field observations in this study as well as the numerous field studies in the early $20^{\text {th }}$ century that the ores are not karst-hosted but are mainly present in veins and disseminated nodules.

\section{REE patterns}

Although the data on REE signatures in Mn oxide ores are often ambiguous with respect to the source of the REEs (Varentsov, 1996), chondrite normalized REE patterns within the ores do show differences between nodules and breccia matrix samples, particularly when comparing Mountain City Window samples to Shenandoah Valley samples (Figure 18). Shenandoah Valley nodules are comparatively depleted in HREEs and enriched in Sm in comparison to the Mountain City Window nodules, which have a flatter REE profile. Some Mountain City Window breccia samples have HREE enrichment, while breccias from the Shenandoah Valley tend to have LREE enrichment. Negative Eu anomalies (although slight) are observed in nodules from both locations, but are only present in breccias from the Mountain City Window, whereas Shenandoah Valley breccias have positive Eu anomalies or do not show $\mathrm{Eu}$ anomalies at all. There is considerable complication in attributing $\mathrm{Eu}$ anomalies to a specific process common to Mn oxide ore deposits, particularly in ores that have multiple generations of recrystallization (Pracejus et al., 1990).

Both sets of nodules contain positive Ce anomalies, all breccias from the Mountain City Window contain positive Ce anomalies (with the exception of the samples containing a high percentage of goethite or quartz, as noted on Figure 18), and only one breccia from the Shenandoah Valley has a positive $\mathrm{Ce}$ anomaly. Positive $\mathrm{Ce}$ anomalies in $\mathrm{Mn}$ oxides are associated with chemical weathering of carbonates (Feng, 2010), as well as the formation of Ce phosphate nanoparticles associated with microbial $\mathrm{Mn}$ oxidation (Ohnuki et al., 2015). Negative Ce anomalies can develop in supergene ore bodies with increasing depth (Pracejus et al., 1990), although none of the ores analyzed in this study exhibit strongly negative $\mathrm{Ce}$ anomalies. Neutral or negative Ce anomalies have been explained by siderophore activity (Loges et al., 2012), but it must be noted that the Ce adsorption process is further complicated by the $\mathrm{pH}$ of the fluid system as well as the presence of humic acids and 
organic molecules (Davranche et al., 2008; Davranche et al., 2005; Pourret et al., 2008). Regardless of mechanism, it is clear that the majority of the Shenandoah Valley breccias have a different geochemical history than the rest of the ore bodies studied.

\section{Additional Analyses}

In addition to the primary FT-IR spectra associated with romanèchite, hollandite-cryptomelane and accessory minerals (goethite, quartz, orthoclase, and various clays), the interiors of six $\mathrm{Mn}$ oxide samples analyzed from the Mountain City Window region also show peaks of varying intensity at 2925 and $2850 \mathrm{~cm}^{-1}$, which correspond to aliphatic methylene biopolymer compounds (representative examples shown in Figure 19). These compounds are found in the lipid fraction of both living and fossil bacterial cells (Igisu et al., 2009) and fossilized plant cells (Gupta et al., 2007). The silicified matrix and secondary quartz in veins and geode interiors from the Shouns Prospect in the Mountain City Window samples do not contain any visible fluid inclusions, indicating fluid temperatures $<120^{\circ} \mathrm{C}$ for the region during silica replacement and subsequent mineralization. This is supported by the low-temperature, fluid-induced deformation and recrystallization along thrust faults in the Shady Dolomite in the Mountain City Window
(Newman and Mitra, 1994), which potentially released reduced $\mathrm{Mn}$ from the Shady Dolomite into groundwater at temperatures $<300^{\circ} \mathrm{C}$.

\section{MECHANISMS FOR ORE FORMATION}

The field relationships in this study (Figures 2, 3) and in previous studies (Force and Cox, 1991; Hack, 1965; Harder, 1910; Hewett et al., 1918; King et al., 1944; Miller, 1944; Miser, 1950; Stose and Miser, 1922; Stose et al., 1919) suggest that the Appalachian Mn oxide deposits can be stratigraphically, structurally or geomorphologicallycontrolled. However, in both of the ore districts examined here, geomorphologically-controlled nodular $\mathrm{Mn}$ deposits in weathered residuum (Figures 4, 6) appear to also be spatially associated with brittle faults that are silicified, brecciated, and may themselves be mineralized (Figures 4, $5,6)$. Therefore we suggest a causative link between structurally and geomorphologically-controlled deposits at these specific localities, and suggest that $\mathrm{Mn}$ deposits evolved from the bottom up rather than being concentrated from the top down as previously hypothesized (e.g. Rodgers, 1945) with subsequent supergene alteration for both districts and possible biological reworking of the deposits of the Mountain City Window.

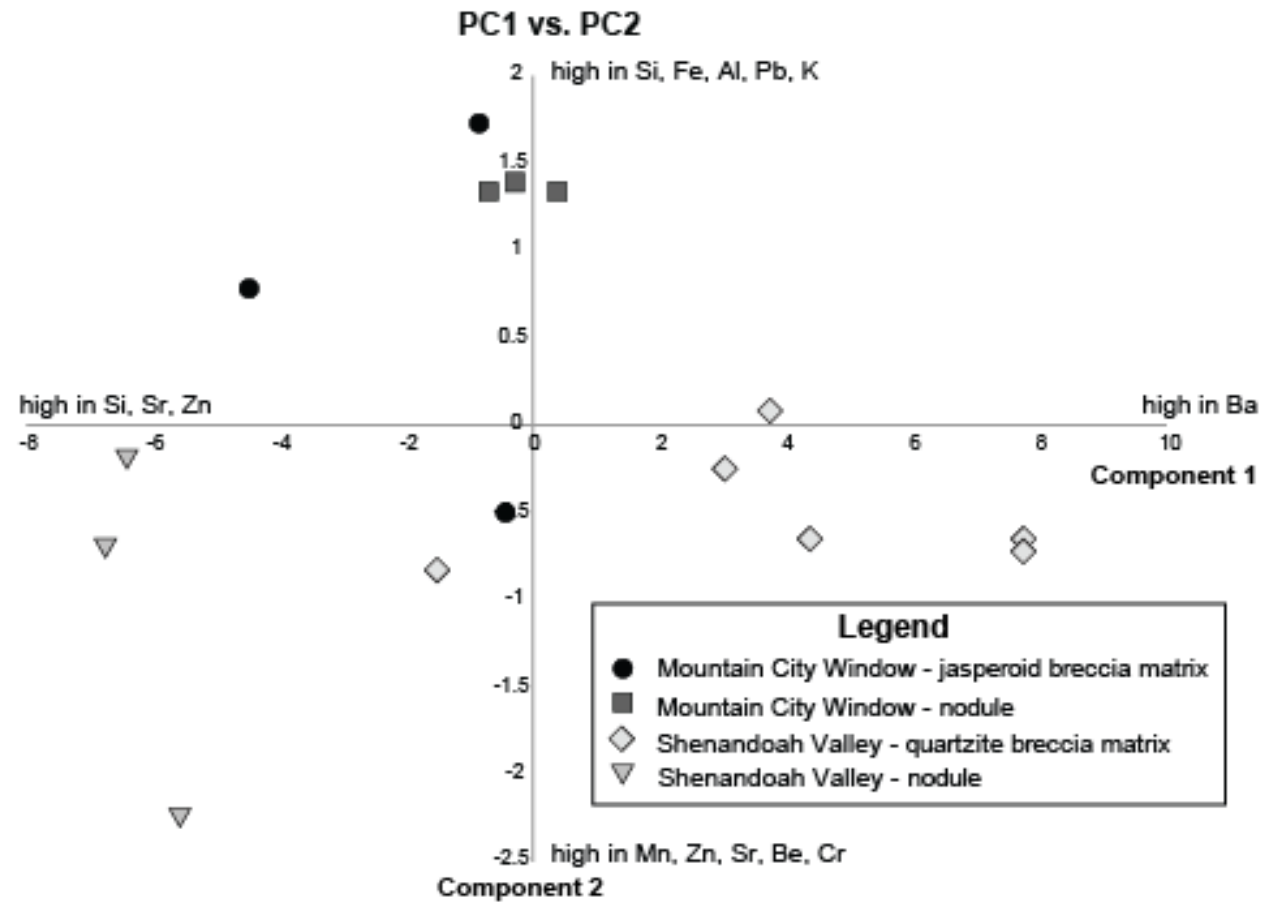

Figure 14. PCA plots according to Ba vs. Si/Sr/Zn (component 1) and Si/Fe/Al/Pb/K vs. Mn/Zn/Sr/Be/Cr (component 2) for all analyzed Mn oxide ores excluding sample DR150124-A2 (which contained abundant quartz) and sample JC-10 (which contained abundant goethite). Shenandoah Valley breccia matrix samples are higher in Ba than Shenandoah Valley nodules. Mountain City Window breccia samples do not show any particular clustering relationship, but Mountain City Window nodules have distinctly higher Si/ Fe/Al/Pb/K and Ba contents than Shenandoah Valley nodules. PCA plots that include samples DR150124-A2 and JC-10 can be found in DR Figure 1. 

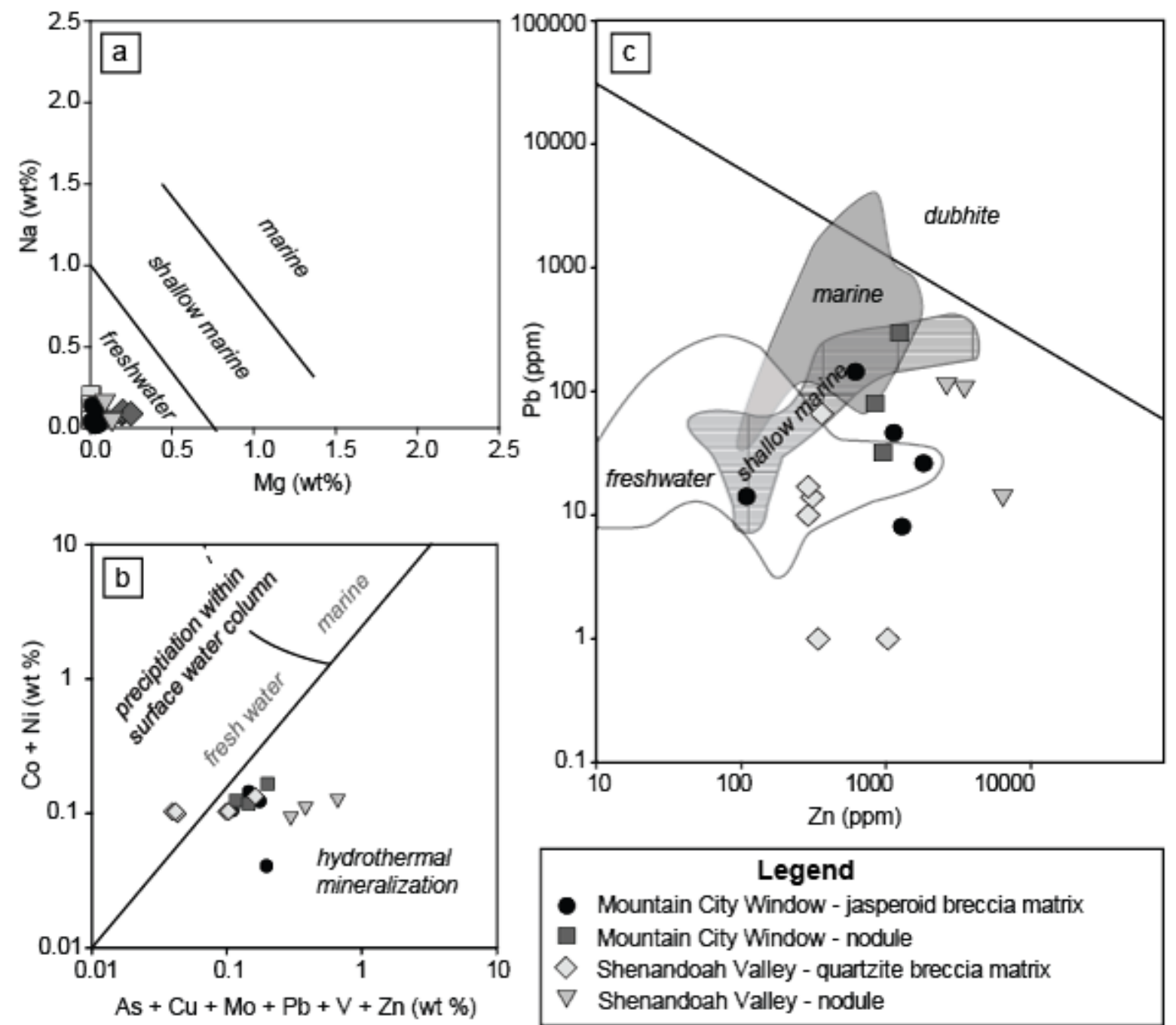

\section{Legend}

Mountain City Window - jasperoid breccia matrix

Mountain City Window - nodule

Shenandoah Valley - quartzite breccia matrix

Shenandoah Valley - nodule

Figure 15. Whole rock geochemical analyses of Mn oxide nodules and breccia matrices from the Mountain City Window and the Shenandoah Valley, modified from Nicholson (1992).

\section{Mountain City Window}

Although the $\mathrm{Mn}$ oxides found in the Mountain City Window ores consist of crystalline hollandite, cryptomelane, and romanèchite, their morphologies suggest that the nucleation source for the crystals could be biological in nature. Evidence for this includes the abundance of filaments with irregular orientations, gravity-induced vertical orientation ("gravity draping"), and interconnected and woven mat-like or concentrically layered fabrics, as seen in Figure 7 and Figure 8 (Hofmann and Farmer, 2000; Hofmann et al., 2008; Melim et al., 2009; Melim et al., 2016). The presence of gas bubbles and micropores in the dendrites and druse stands in sharp contrast to their absence in the surrounding quartz crystals (Figure 7), providing further evidence for biological nucleation (Chafetz and Guidry, 1999). In addition, the organized chains and interconnected clumps of clay spheres containing acicular crystal needles (Figures 7C, 7D) are commonly found in bacterially produced branching masses in travertines (Chafetz et al., 1998), and microbes are known to play an important role in clay sphere formation (Tazaki, 2005 and references therein). Clays have also been shown to act as nucleation surfaces for modern $\mathrm{Mn}$ and Fe oxides ( $\mathrm{Xu}$ and Lee, in press). There are notable similarities in morphology of these ores to those produced in modern biomineralizing environments, such as hot springs in Yellowstone National Park (Cady et al., 2003; Lowe and Braunstein, 2003; Parenteau and Cady, 2010; Smythe, 2015) and in living biofilms on Satsuma-Iwo Jima, a volcanic island in Japan (Tazaki, 2000). The small size $(<1 \mu \mathrm{m})$ of many of the encrusted filaments and sheets suggests that extracellular polymeric substances (EPS) as well as cell surfaces and clay particles may have acted as nucleation sites. EPS are readily mineralized both in the laboratory (Vali et al., 2001) and in a variety of modern and ancient environments (Smythe, 2015; Westall et al., 2000 and references therein). 

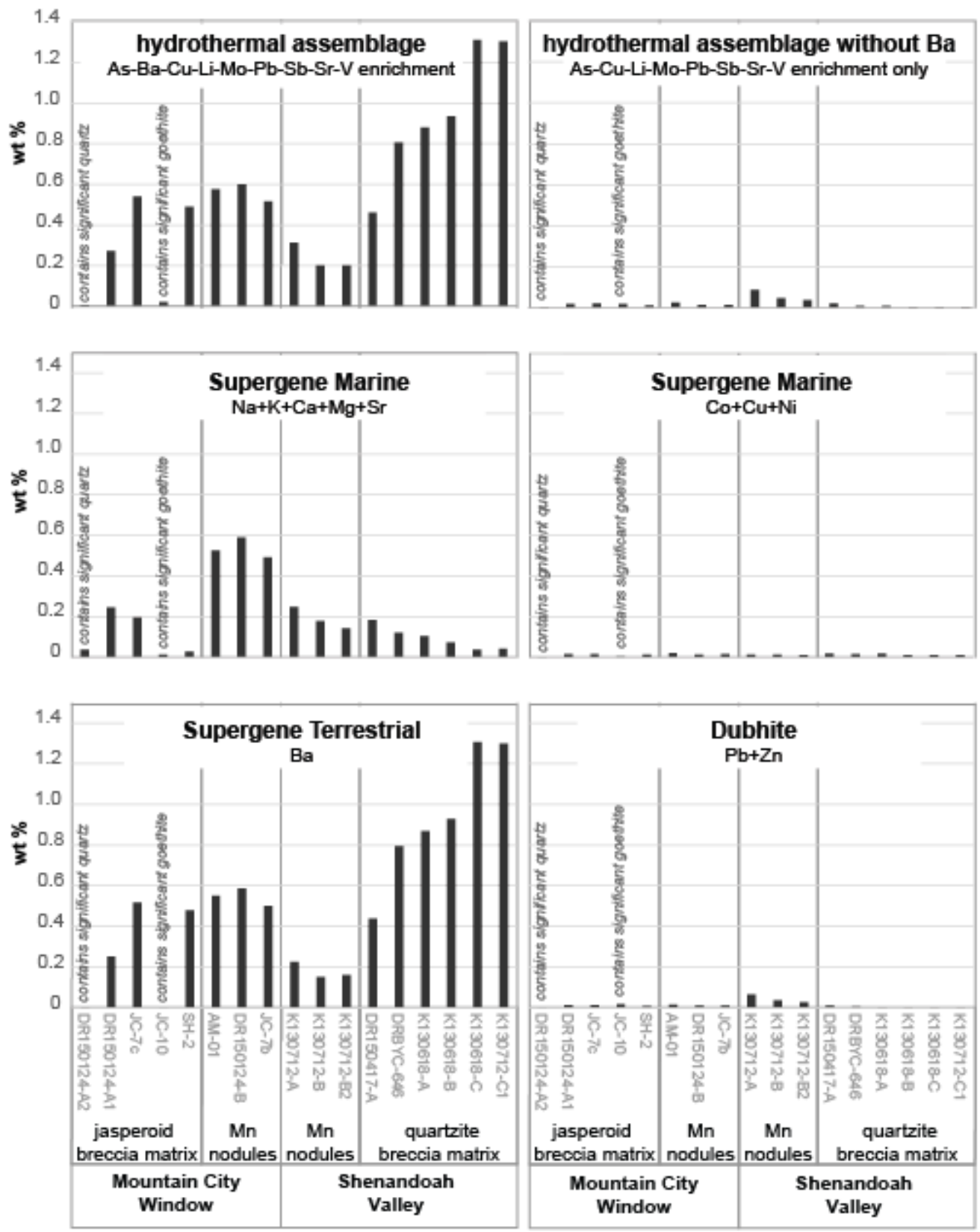

Figure 16. Plots of whole rock geochemical signatures of Mn oxide samples from both the Mountain City Window and the Shenandoah Valley according to the geochemical enrichment assemblages of Nicholson (1992). The high Ba content overprints all of the data within the hydrothermal assemblage, making it indistinguishable from the supergene terrestrial signature (as shown in top left and bottom left graphs). For clarity, a plot showing the hydrothermal assemblage chemistry without $\mathrm{Ba}$ is included (top right).

EPS have also been suggested as the nucleation mechanism for exceptionally well preserved biogenic $\mathrm{Mn}$ oxides in speleothems (Lozano and Rossi, 2012).

Caution must be taken when using morphology alone to determine biogenicity (García-Ruiz et al., 2003; Marshall et al., 2011; McLoughlin et al., 2008), and structures that appear to be biologically produced can also be produced through abiotic processes under a variety of lowtemperature aqueous conditions; however, the presence of aliphatic methylene compounds in the Mountain City Window ores (Figure 19) suggest some sort of biological involvement in ore formation. These biopolymers have been associated with Proterozoic bacteria (Igisu et al., 2009), Silurian cryptospores (Steemans et al., 2010), the in situ polymerization of lipid components of leaves and arthropods during fossilization (Gupta et al., 2007), organic acids in soils (Malcolm, 1990), and are preserved in modern ferromanganese deposits in caves (Estes et al., 2016). 


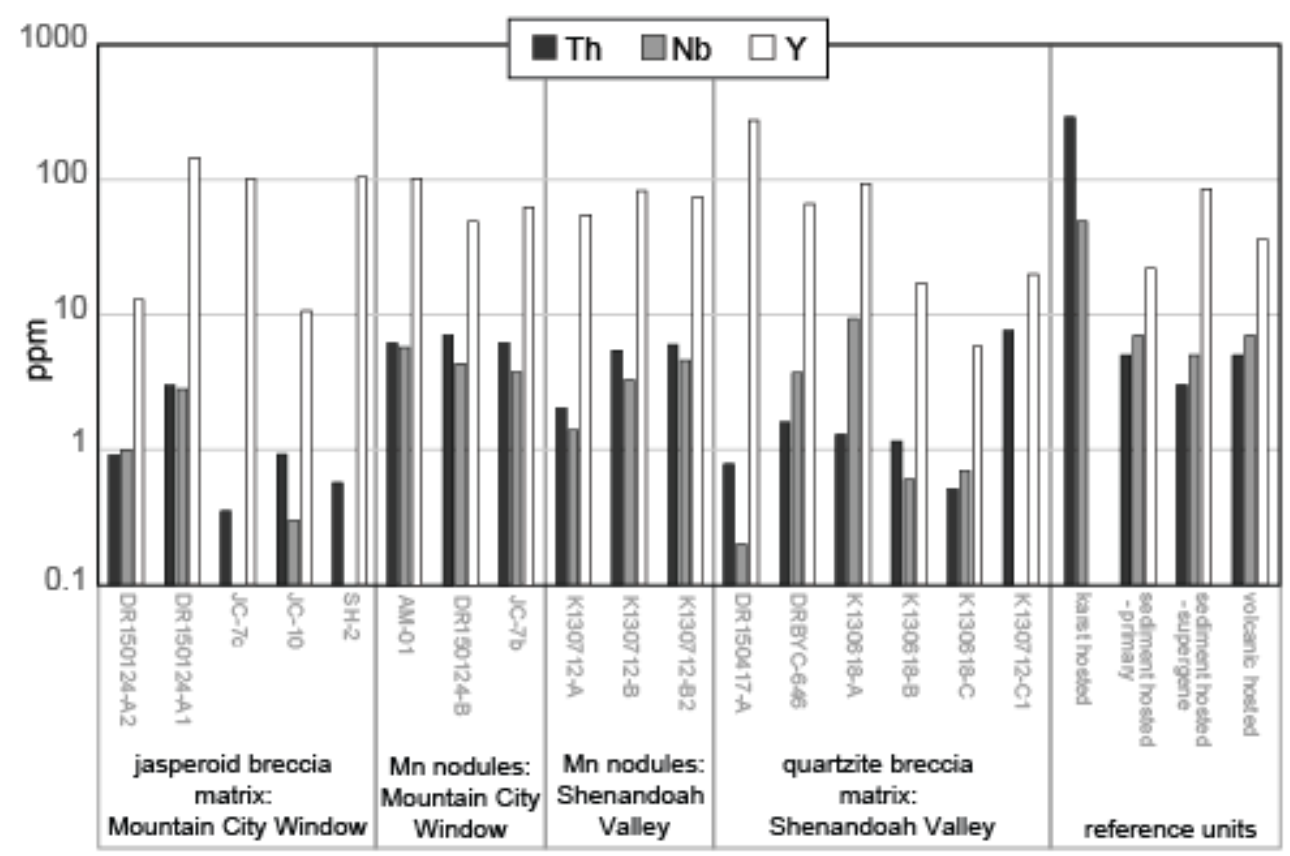

Figure 17. Bar plots of total $\mathrm{Th}, \mathrm{Nb}$, and $\mathrm{Y}$ in samples from the Mountain City Window and the Shenandoah Valley, showing that these ores are incompatible with a karst-hosted Mn oxide deposit due to their high Y values. Reference units from Maynard (2010).

As the secondary quartz mineralization in the Mountain City Window silicified breccia occurred at temperatures of $<120^{\circ} \mathrm{C}$, the subsequent $\mathrm{Mn}$ oxide mineralization can also be assumed to have occurred at $<120^{\circ} \mathrm{C}$, as higher temperatures would both overprint the fluid inclusion temperatures, and likely result in the precipitation of other hydrothermal minerals. The temperature information preserved by the (lack of) fluid inclusions and the absence of accessory hydrothermal minerals suggest that $\mathrm{Mn}$ oxide mineralization in the Mountain City Window occurred within a relatively shallow groundwater system rather than a deep, hot hydrothermal system. Although $\mathrm{Fe}$ oxides can precipitate abiotically in natural waters with $\mathrm{pH} \geq 5$, abiotic $\mathrm{Mn}$ oxidation is not thermodynamically favorable in environmental aqueous systems where the $\mathrm{pH}<9$ (Luther, 2010). There is no evidence for alkaline paleogroundwater systems (evidenced by calcite veins, travertine or tufa deposits) surrounding these ores, indicating that $\mathrm{pH}$ values in groundwater or percolating vadose zone water were likely $<7$. The $\mu \mathrm{m}$-scale proximity and interlayering of both $\mathrm{Fe}$ and $\mathrm{Mn}$ oxides in the breccia samples suggests that significant differences in redox or $\mathrm{pH}$ conditions were unlikely; and that Mn oxidation was likely triggered by the presence of biologically mediated enzymatic compounds, i.e. reactive oxygen and/or organic species (for details of these reactions, see Luther, 2010).

Given these constraints on the fluid source and the presence of biopolymer compounds, it appears that subsurface microbial $\mathrm{Mn}$ oxidation is the most reasonable explanation for the precipitation of the preserved forms of $\mathrm{Mn}$ oxides in the Mountain City Window, as enzymatic oxidation of reduced $\mathrm{Mn}$ by microorganisms can accelerate the rates of $\mathrm{Mn}$ oxidation by up to 5 orders of magnitude compared to abiotic reactions (Tebo et al., 2004), and microbially mediated $\mathrm{Mn}$ oxides are produced in a variety of modern aqueous environments (see reviews by Carmichael and Bräuer, 2015; Edwards et al., 2005).

Mn oxides from the Mountain City Window do differ, however, from modern $\mathrm{Mn}$ oxide deposits with a known biogenic origin, in that the Mountain City Window samples have a higher degree of crystalline order. To date, all of the known $\mathrm{Mn}$ oxides formed by microorganisms either in the laboratory or via in situ field cultures have been composed of poorly crystalline birnessite-group minerals (layer structure Mn oxides) or poorly crystalline todorokite group minerals ( $3 \times 3$ tunnel structure Mn oxides) (see reviews by Saratovsky et al., 2006; Spiro et al., 2010; Tebo et al., 2004). It is possible that gradual reordering of tiny, poorly crystalline Mn oxide crystals may lead to increased crystallinity over time (described in laboratory experiements by Hinkle et al., 2016; Spilde et al., 2005). This recrystallization process has not been observed in cave systems where microbial $\mathrm{Mn}$ deposits have ages of 1 Ma (Rossi et al., 2010), however, and the reason for these discrepancies remains unresolved within the literature at this time. It is possible that the growth of the highly ordered crystals in these ores formed via an oriented attachment mechanism using available Mn oxide microcrystals produced on cell or EPS surfaces as nucleation sites (Banfield et al., 2000; Fang et al., 2011; Smythe, 2015). This latter coupled biotic/abiotic crystallization mechanism is consistent with the presence of 
radiating crystals which increase in size from the nucleation sites (Figures 7E, 8) and have a high degree of crystallinity.

In most large ore bodies, $\mathrm{Mn}$ oxide ores have been assumed to have an abiotic source (Maynard, 2003; Maynard, 2010; Roy, 1992), although several studies do suggest a biogenic origin for Mn oxide oncolites and pisoliths deposited in shallow marine systems (Gutzmer et al., 2002; Ostwald, 1990; Reolid and Nieto, 2010), and for those associated with cherts or black shales (Hein and Koski, 1987; Polgári et al., 2012). Supergene enrichment due to

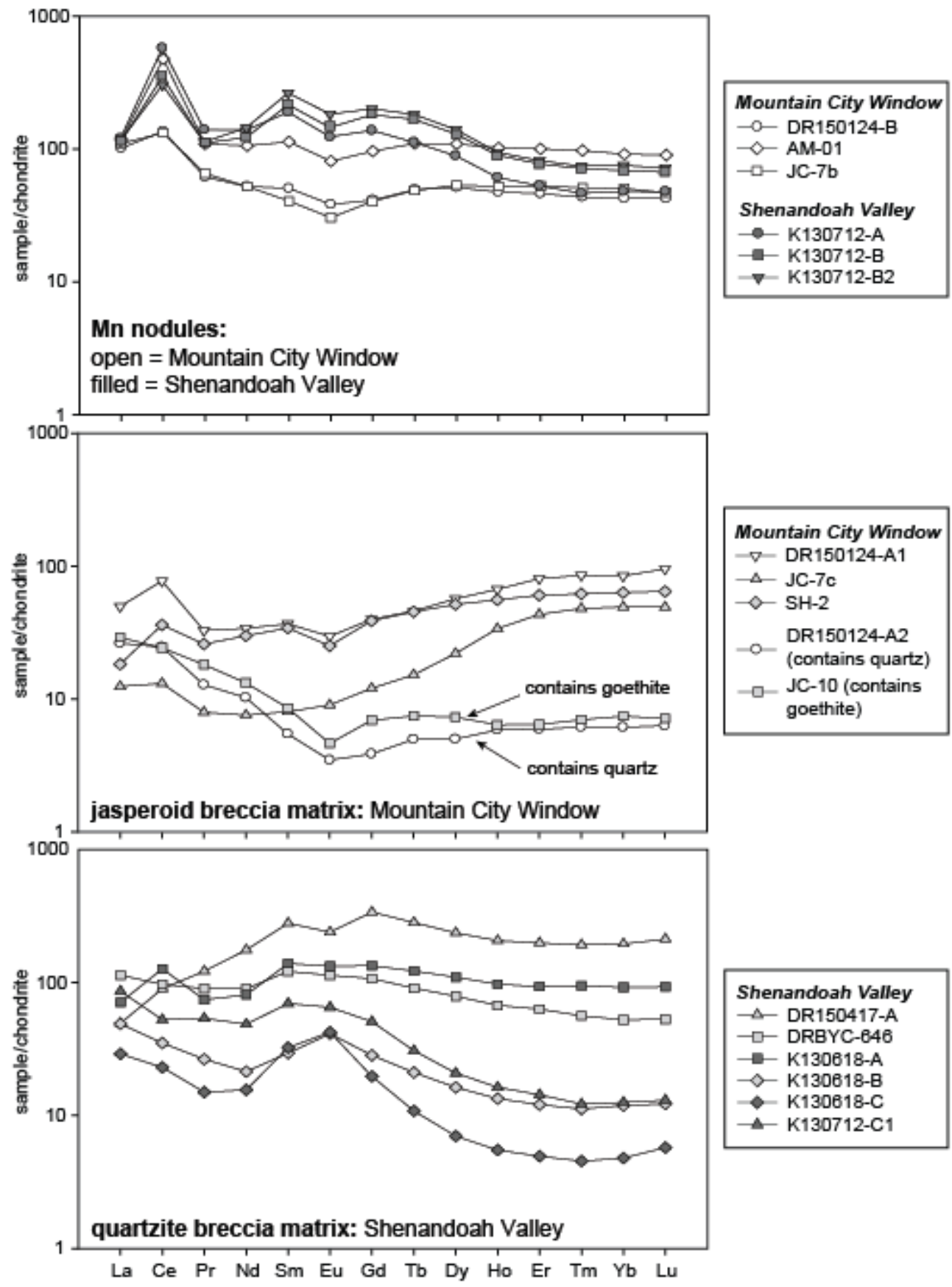

Figure 18. Chondrite-normalized rare earth element (REE) plot for breccia matrices and nodules from the Mountain City Window and the Shenandoah Valley show marked differences in REE signatures between these two locations. Nodules from the Mountain City Window have a flatter REE profile than those of the Shenandoah Valley, although both contain positive Ce anomalies. Shenandoah Valley nodules are comparatively depleted in HREEs and enriched in Sm compared to Mountain City Window nodules. Some Mountain City Window breccia samples have negative Eu anomalies and show enrichment in HREEs, while breccias from the Shenandoah Valley tend to have LREE enrichment, few noticeable Ce anomalies, and positive or neutral Eu anomalies. 


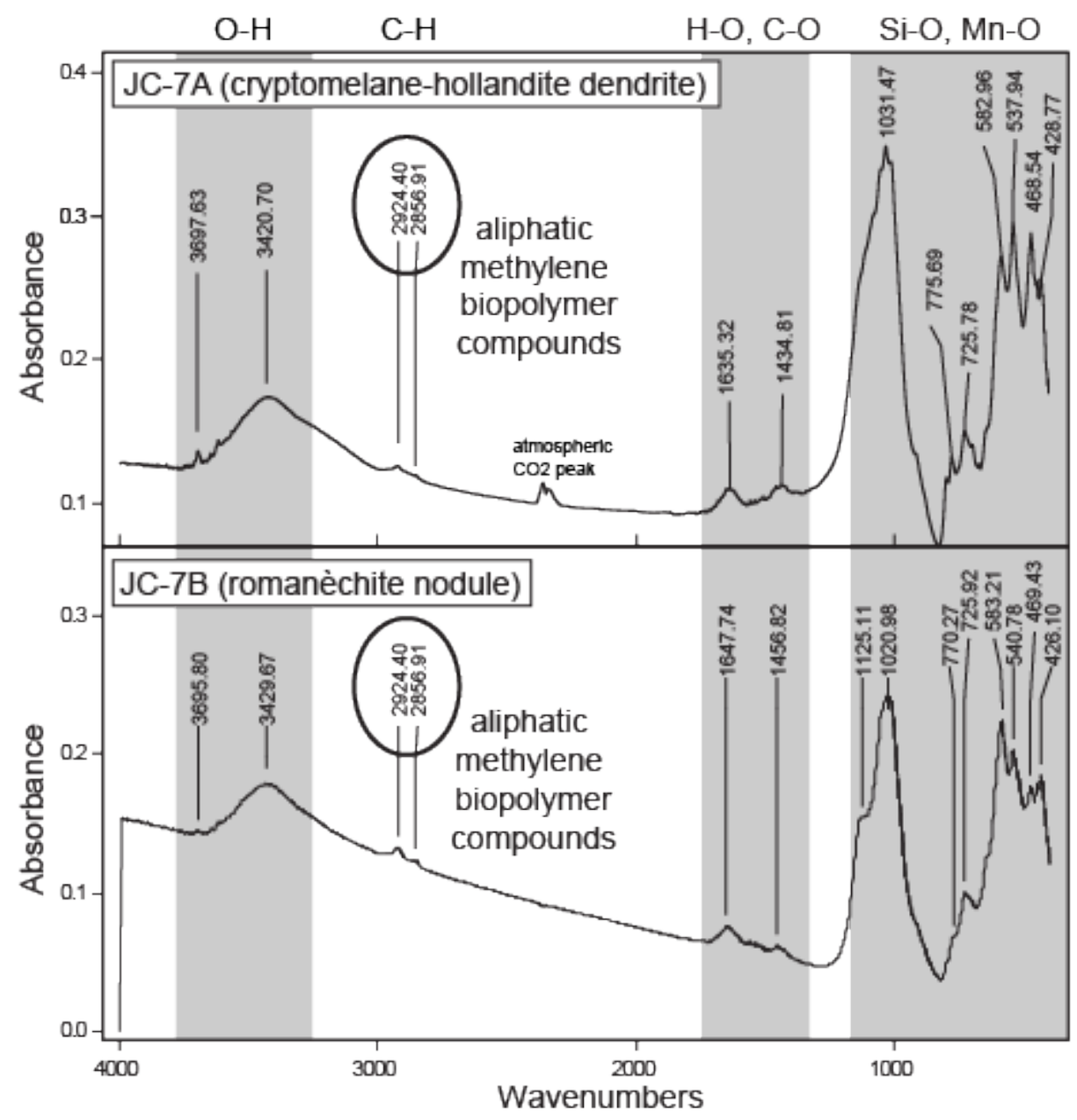

Figure 19. Example of FT-IR spectra showing aliphatic methylene biopolymer compounds (at 2924 and $2857 \mathrm{~cm}-1$ ) in dendrites (top) and romanèchite nodules (bottom) from the Shouns Prospect in the Mountain City Window. Gray bands represent non-organic peaks associated with the Mn oxide crystal structure ( $\mathrm{Si}-\mathrm{O}, \mathrm{Mn}-\mathrm{O}, \mathrm{C}-\mathrm{O}, \mathrm{H}-\mathrm{O}$ stretching). The unshaded $\mathrm{C}-\mathrm{H}$ area is where organic compounds plot.

weathering of existing deposits is consistent with the low temperature of associated quartz mineralization $\left(<120^{\circ} \mathrm{C}\right)$ at the Shouns Prospect in the Mountain City Window, as well as a biological source of $\mathrm{Mn}$ oxide formation, as downwardmoving $\mathrm{Mn}^{2+}$ rich fluids would have originated from porewaters in organic-rich soils containing a variety of common Mn oxidizing microbes (He et al., 2008).

\section{Shenandoah Valley}

Stose et al. (1919) noted five types of structural settings for the ore deposits that were mined along the western foot of the Blue Ridge within the Shenandoah Valley of Virginia. Of these, the first type were deposits that occurred "in a zone of decomposed calcareous shale and cherty dolomite that lies above, and within 200 feet of, the top of the Antietam Sandstone, the beds dipping toward the Shenandoah Valley at angles that range from $30^{\circ}$ to $60^{\circ}$ " (Stose et al., 1919, p. 51). These types of deposits were common, and for this reason the authors attributed some stratigraphic control to the origin of the manganese at or near the contact between the Antietam Sandstone and the overlying Shady Dolomite. The second (and most common) type of deposit included those within shallow synclines or troughs formed within the upper Antietam Sandstone; these were considered most favorable for ore accumulation by the authors, and were the setting for the extremely productive mines at Crimora, Virginia. The third and fourth types of occurrences described by Stose et al. (1919) were as fillings or cements within crushed and brecciated zones of Antietam Sandstone, or along discrete faults. These were not thought to be common occurrences; however, the authors admitted that, "The relation of deposits along fault zones and in brecciated zones in quartzite or shale to surface features has not been thoroughly studied and will not be discussed" (Stose et al., 1919, p. 54). The fifth type of ore setting was deposits found within terrace gravels or reworked as fragments from other ore types. 
Our samples from the Shenandoah Valley along the western foot of the Blue Ridge were all obtained in close association with brecciated quartz sandstone. The Mn oxide cemented breccia bodies appear to have been formed within zones of localized NNW oriented cross-strike faulting, that evidently post-dates the main thrust faulting that placed the older crystalline and siliciclastic rocks of the Blue Ridge province atop the younger carbonate rocks of the Shenandoah Valley (Figure 3). Interestingly, even the massive manganiferous nodules that had replaced weathered alluvial deposits from the Stanley Mine prospect are located near a zone of brecciated Antietam Sandstone that occurs along an across-strike vertical fault (Figure 6). The breccia in the fault zone is also highly weathered, and the matrix consists of limonite and other iron oxy-hydroxides (Figure 6). These cross-strike faults are often difficult to map due to the thick blanket of colluvium and alluvium covering the bedrock and they may be more abundant and more intimately associated with other $\mathrm{Mn}$ oxide deposits than currently recognized.

The presence of lithiophorite cross-cut by hollandite-cryptomelane in the Shenandoah Valley samples (Figure 10A) is further evidence for multiple generations of mineralization in the northern Virginia deposits. Field relationships and textures suggest that deeper fluids likely traveled upward along the numerous faults, where $\mathrm{Mn}$ oxides were deposited as breccia matrix. These matrix minerals later experienced supergene alteration resulting in the formation of hollandite-cryptomelane minerals. The overgrowths of hollandite-cryptomelane on lithiophorite and the cross-cutting relationships between the two minerals (shown in Figures 10A, 10D) support the hypothesis of two disparate generations of $\mathrm{Mn}$ oxidation within the Shenandoah Valley. Fluid flow was initially bottom up, forming hydrothermal textures, minerals, and geochemical signatures, followed by top down during supergene alteration (likewise shown by mineralogy and geochemical signatures).

Force and Cox (1991) undertook studies to determine the origin of the manganese in the better-known mining districts in northern Virginia. They analyzed samples of intact Shady Dolomite and other carbonate bedrock exposures close to manganese ore deposits to test the hypothesis that the source of the manganese was derived from weathering of the primary carbonate. For the deposits along the foot of the Blue Ridge, it was concluded that, "The degree of manganese enrichment required to form a typical supergene concentration from average parent rocks is about 800 times in this area. To contend that all this enrichment has resulted only from weathering strains one's credibility" (Force and Cox, 1991, p. A6). Thus, another more concentrated source for the $\mathrm{Mn}$ at each site is probable. Given the field relations observed at the Stanley prospect in Virginia and at the Shouns Prospect in Tennessee, such a source is likely to have been early-formed $\mathrm{Mn}$ mineralization within brecciated host rock along or adjacent to high angle normal or reverse faults. This finding contrasts with prevailing conceptualizations that the source of the Mn had been disseminated within the carbonate sediments of rocks adjacent to ore deposits.

\section{CONCLUDING REMARKS}

The $\mathrm{Mn}$ oxide ores of the Appalachians have been studied in detail for the first time in more than 50 years, and our results using contemporary analytical techniques stand in significant contrast to many of the conclusions from the studies of the early-mid 1900s. We have documented a close local association between the occurrence of brecciahosted $\mathrm{Mn}$ oxide cements and concretionary forms of $\mathrm{Mn}$ oxide deposits. This association suggests that the brecciahosted deposits represent an earlier-formed emplacement of $\mathrm{Mn}$ oxide relative to the nodular, concretionary deposits. Nodular, concretionary forms likely represent a later remobilization of $\mathrm{Mn}$ sourced from the breccia cements. While the mineralogy and microstructures of breccia cements tend to favor inorganically precipitated Mn oxides in the Shenandoah Valley, a combination of microbiallyassisted Mn oxide nucleation followed by inorganic Mn oxide precipitation within the Shouns Prospect in Tennessee appears likely.

Although all known biogenic Mn oxides to date have been $\mathrm{nm}$-scale and poorly crystalline birnessite and todorokite group minerals (see reviews by Spiro et al., 2010; Tebo et al., 2004; Tebo et al., 2005), this study shows for the first time that massive and highly crystalline, barium-rich Mn oxide minerals such as romanèchite and hollandite can also form in response to microbial activity (particularly as nucleation along extracellular polymeric substances) within both Mn-rich concretionary nodules that replace host rock and sediment, as well as within breccia matrix deposits. Nevertheless, the $\mathrm{Mn}$ oxide mineralizations that formed within brecciated bodies of quartz sandstone in the Shenandoah Valley do not show any clear linkage to biological activity, and may have been entirely inorganically precipitated.

Geochemical characterization of the Mn deposits in this study showed a clear distinction between the $\mathrm{Mn}$ oxides hosted within the matrix cements of quartz sandstone breccias, and those hosted within a breccia matrix of silicified shaly carbonate or hosted within nodules that encase sedimentary material. Multiple overprinting generations of $\mathrm{Mn}$ oxide minerals as observed under magnification are likely responsible for obscuring primary geochemical signatures of the original ore-forming solutions. Carbonate rocks do not appear to be as plausible a source for the Mn enrichments as once believed, and further study may reveal a closer association between Mn ore deposits and zones of faulting or brecciation of rocks hosting $\mathrm{Mn}$ deposits than has been documented in the past within the Appalachians. 


\section{ACKNOWLEDGEMENTS}

The authors are grateful for the fieldwork assistance of A. Merschat, F. Webb, A. Pitts, S. Whitmeyer and G. Casale, and for the support of $G$. Hou at the Dewel Microscopy Facility at Appalachian State University. A. Love, A. Pitts and J. Benton assisted with sample preparation, H. Belkin assisted with SEM analyses, J. Jackson assisted with XRD powder analyses, and R. Bodnar generously performed fluid inclusion analyses. J. Post performed single crystal XRD measurements and provided FEI NanoSEM images. J. Schiffbauer performed FIB-EM measurements. S. Hageman assisted with PCA on whole rock geochemistry data. E. Hope Wolfe assisted with powder XRD analyses. Major funding for this research is from a NC Space Grant New Investigators Award to S.K. Carmichael, with additional support from Appalachian State University and from the National Cooperative Geologic Mapping Program of the U.S. Geological Survey. The authors thank Xuifang Xu, Michael Spilde, Arthur Merschat, and an anonymous reviewer for their helpful comments and corrections. Any use of trade, firm, or product names is for descriptive purposes only and does not imply endorsement by the U.S. Government

\section{REFERENCES}

Adams, M. G., and Su, Q., 1996, The nature and timing of deformation in the Beech Mountain thrust sheet between the Grandfather Mountain and Mountain City windows in the Blue Ridge of northwestern North Carolina: Journal of Geology, p. 197-213.

Banfield, J. F., Welch, S. A., Zhang, H., Ebert, T. T., and Penn, R. L., 2000, Aggregation-Based Crystal Growth and Microstructure Development in Natural Iron Oxyhydroxide Biomineralization Products: Science, v. 289, no. 5480, p. 751-754.

Bikerman, M., Myers, T., Prout, A., and Smith, R., 1999, Geology: Testing the Feasibility of K-Ar Dating of Pennsylvania Cryptomelanes [Potassium Manganese Oxides]: Journal of the Pennsylvania Academy of Science, v. 72, p. 109-114.

Cady, S. L., Farmer, J. D., Grotzinger, J. P., Schopf, J. W., and Steele, A., 2003, Morphological biosignatures and the search for life on Mars: Astrobiology, v. 3, no. 2, p. 351-368.

Carmichael, S. K., and Bräuer, S. L., 2015, Microbial diversity and manganese cycling: a review of $\mathrm{Mn}$ oxidizing microbial cave communities, in Engel, A. S., ed., Microbial Life of Cave Systems, Volume 3: Boston, MA, De Gruyter, p. 137-160.

Chafetz, H. S., Akdim, B., Julia, R., and Reid, A., 1998, Mnand Fe-rich black travertine shrubs; bacterially (and nanobacterially) induced precipitates: Journal of Sedimentary Research, v. 68, no. 3, p. 404-412.

Chafetz, H. S., and Guidry, S. A., 1999, Bacterial shrubs, crystal shrubs, and ray-crystal shrubs: bacterial vs. abiotic precipitation: Sedimentary Geology, v. 126, no. 14, p. 57-74.

Dana, J. D., 1877, On the relations of the geology of Vermont to that of Berkshire: American Journal of Science, v. Series 3 Vol. 14, no. 80, p. 132-139.

Davranche, M., Pourret, O., Gruau, G., Dia, A., Jin, D., and Gaertner, D., 2008, Competitive binding of REE to humic acid and manganese oxide: impact of reaction kinetics on development of cerium anomaly and REE adsorption: Chemical Geology, v. 247, no. 1, p. 154-170.

Davranche, M., Pourret, O., Gruau, G., Dia, A., and Le CozBouhnik, M., 2005, Adsorption of REE (III)-humate complexes onto $\mathrm{MnO}$ 2: experimental evidence for cerium anomaly and lanthanide tetrad effect suppression: Geochimica et Cosmochimica Acta, v. 69, no. 20, p. 4825-4835.

Edwards, K. J., Bach, W., and McCollom, T. M., 2005, Geomicrobiology in oceanography: microbe-mineral interactions at and below the seafloor: Trends in Microbiology, v. 13, no. 9, p. 449-456.

Estes, E. R., Andeer, P. F., Nordlund, D., Wankel, S. D., and Hansel, C. M., 2016, Biogenic manganese oxides as reservoirs of organic carbon and proteins in terrestrial and marine environments: Geobiology, 10.1111/gbi.12195.

Fang, P.-A., Conway, J. F., Margolis, H. C., Simmer, J. P., and Beniash, E., 2011, Hierarchical self-assembly of amelogenin and the regulation of biomineralization at the nanoscale: Proceedings of the National Academy of Sciences, v. 108, no. 34, p. 14097-14102.

Feng, J.-L., 2010, Behaviour of rare earth elements and yttrium in ferromanganese concretions, gibbsite spots, and the surrounding terra rossa over dolomite during chemical weathering: Chemical Geology, v. 271, no. 3, p. 112-132.

Foose, R. M., 1945, Manganese Minerals of Pennsylvania, Mineral Resource Report: 27, Pennsylvania Geological Survey Department of Environmental Resources Topographic and Geologic Survey, $112 \mathrm{p}$.

Force, E. R., and Cox, L. J., 1991, Manganese contents of some sedimentary rocks of Paleozoic age in Virginia: U.S. Geological Survey Bulletin 1916, United States Geological Survey, $41 \mathrm{p}$.

García-Ruiz, J. M., Hyde, S. T., Carnerup, A. M., Christy, A. G., Van Kranendonk, M. J., and Welham, N. J., 2003, Self-Assembled Silica-Carbonate Structures and Detection of Ancient Microfossils: Science, v. 302, no. 5648, p. 1194-1197.

Gupta, N. S., Briggs, D. E. G., Collinson, M. E., Evershed, R. P., Michels, R., Jack, K. S., and Pancost, R. D., 2007, Evidence for the in situ polymerisation of labile aliphatic organic compounds during the preservation of fossil leaves: Implications for organic matter preservation: Organic Geochemistry, v. 38, no. 3, p. 499-522.

Gutzmer, J., Schaefer, M. O., and Beukes, N. J., 2002, Red Bed-Hosted Oncolitic Manganese Ore of the 
Paleoproterozoic Soutpansberg Group, Bronkhorstfontein, South Africa: Economic Geology, v. 97 , no. 6 , p. 1151-1166.

Hack, J. T., 1965, Geomorphology of the Shenandoah Valley, Virginia and West Virginia, and origin of the residual ore deposits: Geological Survey Professional Paper 484, United States Geological Survey, 84 p.

Hageman, S. J., and Miller III, W., 2016, New fossil discoveries in the Chilhowee Group (southern Appalachians, USA): evidence for the EdiacaranCambrian transition,'Cambrian Agronomic Revolution', and earliest trilobites at the southern margin of Laurentia.: Neues Jahrbuch für Geologie und Paläontologie, v. 281, no. 2, p. 135-154.

Hammer, Ø., Harper, D. A. T., and Ryan, P. D., 2001, PAST: Paleontological statistics software package for education and data analysis (version 3.12), Palaeontologia Electronica, Volume 4(1), $9 \mathrm{p}$.

Harder, E. C., 1910, Manganese deposits of the United States - with sections on foreign deposits, chemistry, and uses: Bulletin 427, United States Geological Survey, 298 p.

He, J., Zhang, L., Jin, S., Zhu, Y., and Liu, F., 2008, Bacterial communities inside and surrounding soil ironmanganese nodules: Geomicrobiology Journal, v. 25, no. 1, p. 14-24.

Hearn, P. P., Sutter, J. F., and Belkin, H. E., 1987, Evidence for Late-Paleozoic brine migration in Cambrian carbonate rocks of the central and southern Appalachians: Implications for Mississippi Valley-type sulfide mineralization: Geochimica et Cosmochimica Acta, v. 51, no. 5, p. 1323-1334.

Hein, J. R., and Koski, R. A., 1987, Bacterially mediated diagenetic origin for chert-hosted manganese deposits in the Franciscan Complex, California Coast Ranges: Geology, v. 15, no. 8, p. 722-726.

Hewett, D. F., 1916, Some manganese mines in Virginia and Maryland: Contributions to Economic Geology Part I, 1916, United States Geological Survey Bulletin 640, United States Geological Survey, p. 37-71.

Hewett, D. F., and Fleischer, M., 1960, Deposits of the manganese oxides: Economic Geology, v. 55, no. 1, p. 1-55.

Hewett, D. F., Stose, G. W., Katz, F. J., and Miser, H. D., 1918, Possibilities for manganese ore on certain undeveloped tracts in the Shenandoah Valley, Virginia: Contributions to economic geology, 1917, Part I, Metals and nonmetals except fuels, p. 271-304.

Hinkle, M. A. G., Flynn, E. D., and Catalano, J. G., 2016, Structural response of phyllomanganates to wet aging and aqueous Mn(II): Geochimica et Cosmochimica Acta, v. 192 , p. $220-234$.

Hoffman, J. N., 1957, Manganese - its minerals, deposits and uses: Circular Number 49, The Mineral Industries Experiment Station, College of Mineral Industries, Pennsylvania State University, 126 p.
Hofmann, B. A., and Farmer, J. D., 2000, Filamentous fabrics in low-temperature mineral assemblages: are they fossil biomarkers? Implications for the search for a subsurface fossil record on the early Earth and Mars: Planetary and Space Science, v. 48, no. 11, p. 10771086.

Hofmann, B. A., Farmer, J. D., von Blanckenburg, F., and Fallick, A. E., 2008, Subsurface filamentous fabrics: an evaluation of origins based on morphological and geochemical criteria, with implications for exopaleontology: Astrobiology, v. 8, no. 1, p. 87-117.

Hull, J., LaForge, L., and Crane, W., 1919, Report on the manganese deposits of Georgia: Bulletin No. 35, Second Report on Manganese, Geological Society of Georgia, $139 \mathrm{p}$.

Igisu, M., Ueno, Y., Shimojima, M., Nakashima, S., Awramik, S. M., Ohta, H., and Maruyama, S., 2009, Micro-FTIR spectroscopic signatures of Bacterial lipids in Proterozoic microfossils: Precambrian Research, v. 173, no. 1, p. 19-26.

Jébrak, M., 1997, Hydrothermal breccias in vein-type ore deposits: a review of mechanisms, morphology and size distribution: Ore Geology Reviews, v. 12, no. 3, p. 111134.

Jonas, A. I., 1942, Manganese-bearing veins in southwestern Virginia: Economic Geology, v. 37, no. 5, p. $408-423$.

Kesler, S. E., Vennemann, T. W., Frederickson, C., Breithaupt, A., Vazquez, R., and Furman, F. C., 1997, Hydrogen and oxygen isotope evidence for origin of MVT-forming brines, southern Appalachians: Geochimica et Cosmochimica Acta, v. 61, no. 7, p. 15131523.

Kesler, T. L., 1941, Structure and ore deposition at Cartersville, Georgia: American Institute of Mining and Metallurgical Engineers Transactions, v. 144, p. 276-293.

King, P. B., and Ferguson, H. W., 1960, Geology of Northeastmost Tennessee: Geological Survey Professional Paper 311, United States Geological Survey, $136 \mathrm{p}$.

King, P. B., Jewell, W. B., Ferguson, H. W., Craig, L. C., and Rodgers, J., 1944, Geology and manganese deposits of northeastern Tennessee: Bulletin 52, Tennessee Division of Geology, $275 \mathrm{p}$.

Loges, A., Wagner, T., Barth, M., Bau, M., Göb, S., and Markl, G., 2012, Negative Ce anomalies in Mn oxides: the role of $\mathrm{Ce} 4+$ mobility during water-mineral interaction: Geochimica et Cosmochimica Acta, v. 86, p. 296-317.

Lowe, D. R., and Braunstein, D., 2003, Microstructure of high-temperature (>73 C) siliceous sinter deposited around hot springs and geysers, Yellowstone National Park: the role of biological and abiological processes in sedimentation: Canadian Journal of Earth Sciences, v. 40, no. 11, p. 1611-1642. 
Lozano, R. P., and Rossi, C., 2012, Exceptional preservation of Mn-oxidizing microbes in cave stromatolites (El Soplao, Spain): Sedimentary Geology, v. 255, p. $42-55$.

Luther, G. W., 2010, The role of one-and two-electron transfer reactions in forming thermodynamically unstable intermediates as barriers in multi-electron redox reactions: Aquatic Geochemistry, v. 16, no. 3, p. 395420.

Malcolm, R. L., 1990, The uniqueness of humic substances in each of soil, stream and marine environments: Analytica Chimica Acta, v. 232, no. 0, p. 19-30.

Marshall, C. P., Emry, J. R., and Marshall, A. O., 2011, Haematite pseudomicrofossils present in the 3.5-billionyear-old Apex Chert: Nature Geoscience, v. 4, no. 4, p. 240-243.

Maynard, J., 2003, Manganiferous sediments, rocks, and ores, in Heinrich, D. H., and Karl, K. T., eds., Treatise on Geochemistry, Volume 7: Oxford, Pergamon, p. 289-308.

Maynard, J. B., 2010, The Chemistry of Manganese Ores through Time: A Signal of Increasing Diversity of EarthSurface Environments: Economic Geology, v. 105, no. 3, p. 535-552.

McLoughlin, N., Wilson, L. A., and Brasier, M. D., 2008, Growth of synthetic stromatolites and wrinkle structures in the absence of microbes - implications for the early fossil record: Geobiology, v. 6, no. 2, p. 95-105.

Melim, L., Liescheidt, R., Northup, D., Spilde, M., Boston, P., and Queen, J., 2009, A biosignature suite from cave pool precipitates, Cottonwood Cave, New Mexico: Astrobiology, v. 9, no. 9, p. 907-917.

Melim, L. A., Northup, D. E., Boston, P. J., and Spilde, M. N., 2016, Preservation of fossil microbes and biofilm in cave pool carbonates and comparison to other microbial carbonate environments: Palaios, v. 31 , no. 4, p. $177-$ 189.

Merschat, A. J., Southworth, S., McClellan, E., Tollo, R. P., Rankin, D. W., Hooper, S., and Bauer, S., 2014, Key structural and stratigraphic relationships from the northeast end of the Mountain City window and the Mount Rogers area, Virginia-North CarolinaTennessee, in Bailey, C. M., ed., Elevating Geoscience in the Southeastern United States: New Ideas about Old Terranes - Field Guides for the GSA Southeastern Section Meeting, Blacksburg, Virginia, 2014, Volume 35, Geological Society of America, p. 63-101.

Miller, R. L., 1944, Geology and Manganese Deposits of the Glade Mountain District, Virginia: Bulletin 61, Virginia Geological Survey, 150 p.

Miser, H. D., 1950, Manganese deposits of the southeastern states, in Proceedings Symposium on Mineral Resources of the Southeastern United States, Knoxville, TN, University of Tennessee Press, p. 152-169.

Newman, J., and Mitra, G., 1994, Fluid-influenced deformation and recrystallization of dolomite at low temperatures along a natural fault zone, Mountain City window, Tennessee: Bulletin of the Geological Society of America, v. 106, no. 10, p. 1267.

Nicholson, K., 1992, Contrasting mineralogical-geochemical signatures of manganese oxides; guides to metallogenesis: Economic Geology, v. 87, no. 5, p. 12531264.

Ohnuki, T., Jiang, M., Sakamoto, F., Kozai, N., Yamasaki, S., Yu, Q., Tanaka, K., Utsunomiya, S., Xia, X., and Yang, K., 2015, Sorption of trivalent cerium by a mixture of microbial cells and manganese oxides: Effect of microbial cells on the oxidation of trivalent cerium: Geochimica et Cosmochimica Acta, v. 163, p. 1-13.

Ostwald, J., 1990, The biogeochemical origin of the Groote Eylandt manganese oxide pisoliths and ooliths, northern Australia: Ore Geology Reviews, v. 5, no. 5-6, p. 469490.

Parenteau, M. N., and Cady, S. L., 2010, Microbial biosignatures in iron-mineralized phototrophic mats at Chocolate Pots Hot Springs, Yellowstone National Park, United States: Palaios, v. 25, no. 2, p. 97-111.

Penrose, R., 1891, Manganese: its uses, ores, and deposits: Geological Survey of Arkansas Annual Report for 1890, vol. I, Geological Survey of Arkansas, 642 p.

Pierce, W. G., 1944, Cobalt-bearing manganese deposits of Alabama, Georgia, and Tennessee: Bulletin 940-J, Strategic Minerals Investigations, United States Geological Survey, 265-285 p.

Polgári, M., Hein, J. R., Vigh, T., Szabó-Drubina, M., Fórizs, I., Bíró, L., Müller, A., and Tóth, A. L., 2012, Microbial processes and the origin of the Úrkút manganese deposit, Hungary: Ore Geology Reviews, v. 47, no. 0, p. 87-109.

Post, J. E., 1999, Manganese oxide minerals: crystal structures and economic and environmental significance: Proceedings of the National Academy of Sciences, v. 96, p. 3447-3454.

Pourret, O., Davranche, M., Gruau, G., and Dia, A., 2008, New insights into cerium anomalies in organic-rich alkaline waters: Chemical Geology, v. 251, no. 1-4, p. 120-127.

Pracejus, B., Bolton, B. R., Frakes, L. A., and Abbott, M., 1990, Rare-earth element geochemistry of supergene manganese deposits from Groote Eylandt, Northern Territory, Australia: Ore Geology Reviews, v. 5, no. 4, p. 293-314.

Rash, M. R., Wilson, C. G., Carmichael, S. K., and Feierstein, J., 2012, Geologic mapping and field observations of the mode and occurrence of $\mathrm{Mn}$-oxide in the Doe Ridge Culmination, Mountain City, TN, Geological Society of America Abstracts with Programs, Volume 44, p. \#8-4.

Reichert, S. O., 1942, Manganese Resources of East Tennessee: Bulletin 50, State of Tennessee Department of Conservation - Division of Geology, 204 p.

Reolid, M., and Nieto, L. M., 2010, Jurassic Fe-Mn macrooncoids from pelagic swells of the External Subbetic 
(Spain): evidences of microbial origin: Geologica acta, v. 8, no. 2, p. 151-168.

Rodgers, J., 1945, Manganese content of the Shady dolomite in Bumpass Cove, Tennessee: Economic Geology, v. 40, no. 2, p. 129-135.

-, 1948, Geology and mineral deposits of Bumpass Cove, Unicoi and Washington counties, Tennessee, Tennessee Division of Geology Bulletin 54, $82 \mathrm{p}$.

Rossi, C., Lozano, R. P., Isanta, N., and Hellstrom, J., 2010, Manganese stromatolites in caves: El Soplao (Cantabria, Spain): Geology, v. 38, no. 12, p. 1119-1122.

Roy, S., 1992, Environments and processes of manganese deposition: Economic Geology, v. 87, no. 5, p. 12181236.

Saratovsky, I., Wightman, P. G., Pastén, P. A., Gaillard, J.F., and Poeppelmeier, K. R., 2006, Manganese oxides: parallels between abiotic and biotic structures: Journal of the American Chemical Society, v. 128, no. 34, p. 1118811198.

Smoot, J. P., and Southworth, S., 2014, Volcanic rift margin model for the rift-to-drift setting of the late Neoproterozoic-early Cambrian eastern margin of Laurentia: Chilhowee Group of the Appalachian Blue Ridge: Geological Society of America Bulletin, v. 126, no. 1-2, p. 201-218.

Smythe, W. F., 2015, Biomineralization in extreme iron and manganese depositing environments [PhD: Oregon Health \& Science University], 245 p.

Spilde, M. N., Northup, D. E., Boston, P. J., Schelble, R. T., Dano, K. E., Crossey, L. J., and Dahm, C. N., 2005, Geomicrobiology of cave ferromanganese deposits: A field and laboratory investigation: Geomicrobiology Journal, v. 22, no. 3-4, p. 99-116.

Spiro, T. G., Bargar, J. R., Sposito, G., and Tebo, B. M., 2010, Bacteriogenic manganese oxides: Accounts of Chemical Research, v. 43, no. 1, p. 2-9.

Steemans, P., Lepot, K., Marshall, C. P., Le Hérissé, A., and Javaux, E. J., 2010, FTIR characterisation of the chemical composition of Silurian miospores (cryptospores and trilete spores) from Gotland, Sweden: Review of Palaeobotany and Palynology, v. 162, no. 4, p. 577-590.

Stose, A., and Stose, G., 1957, Geology and mineral resources of the Gossan Lead District and adjacent areas in Virginia: Virginia Division of Mineral Resources, Charlottesville, Virginia.

Stose, G. W., 1920, Manganese Ores of the Southern States: Engineering and Mining Journal, v. 110, no. 6, p. 256-262.

Stose, G. W., 1942, Source beds of manganese ore in the Appalachian Valley: Economic Geology, v. 37, no. 3, p. 163-172.

Stose, G. W., and Miser, H. D., 1922, Manganese Deposits of Western Virginia: Bulletin No. XXIII, Virginia Geological Survey, 154 p.
Stose, G. W., Miser, H. D., Katz, F. J., and Hewett, D. F., 1919, Manganese deposits of the west foot of the Blue ridge, Virginia: Bulletin No. XVII, Virginia Geological Survey, $166 \mathrm{p}$.

Stose, G. W., and Schrader, F. C., 1923, Manganese deposits of east Tennessee: Bulletin 737, United States Geological Survey, $154 \mathrm{p}$.

Tazaki, K., 2000, Formation of banded iron-manganese structures by natural microbial communities: Clays and Clay Minerals, v. 48, p. 511-520.

Tazaki, K., 2005, Microbial formation of a halloysite-like mineral: Clays and Clay Minerals, v. 53 , no. 3, p. 224233.

Tebo, B. M., Bargar, J. R., Clement, B. G., Dick, G. J., Murray, K. J., Parker, D., Verity, R., and Webb, S. M., 2004, Biogenic manganese oxides: Properties and mechanisms of formation: Annual Review of Earth and Planetary Sciences, v. 32, p. 287-328.

Vali, H., McKee, M. D., Çiftçioglu, N., Sears, S. K., Plows, F. L., Chevet, E., Ghiabi, P., Plavsic, M., Kajander, E. O., and Zare, R. N., 2001, Nanoforms: a new type of proteinassociated mineralization: Geochimica et Cosmochimica Acta, v. 65 , no. 1 , p. 63-74.

Varentsov, I. M., 1996, Manganese Ores of the Supergene Zone: Geochemistry of Formation, Dordrecht/Boston/London, Kluwer Academic Publishers, $342 \mathrm{p}$.

Watson, T. L., 1909, The manganese ore deposits of Georgia: Economic Geology, v. 4, no. 1, p. 46-55.

Westall, F., Steele, A., Toporski, J., Walsh, M., Allen, C., Guidry, S., McKay, D., Gibson, E., and Chafetz, H., 2000, Polymeric substances and biofilms as biomarkers in terrestrial materials: implications for extraterrestrial samples: Journal of Geophysical Research, v. 105, no. E10, p. 24511-24524,24527.

Whitney, P. R., 1969, Variations of the KRb ratio in migmatitic paragneisses of the northwest Adirondacks: Geochimica et Cosmochimica Acta, v. 33, no. 10, p. 1203-1211.

Wilmarth, M. G., 1938, Lexicon of geologic names of the United States (including Alaska): Bulletin 896, United States Geological Survey, $2396 \mathrm{p}$.

Xu, H., Chen, T., and Konishi, H., 2010, HRTEM investigation of trilling todorokite and nano-phase $\mathrm{Mn}$ oxides in manganese dendrites: American Mineralogist, v. 95 , no. 4, p. 556-562.

$\mathrm{Xu}, \mathrm{H}$., and Lee, S., in press, XRD and TEM studies on nanophase manganese oxides in freshwater ferromanganese nodules from Green Bay, Lake Michigan: Clays and Clay Minerals, https://doi.org/10.1346/CCMN.2016.064032.

${ }^{1}$ GSA Data Repository items 201Xxxx (DR Files 1-4) are available online at www.geosociety.org/pubs/ft20XX.htm, or on request from editing@geosociety.org or Documents Secretary, GSA, P.O. Box 9140, Boulder, CO 80301, USA. 